\title{
THE EFFECT OF OCCUPATIONAL LICENSING ON CONSUMER WELFARE: EARLY MIDWIFERY LAWS AND MATERNAL MORTALITY
}

\author{
D. Mark Anderson \\ Ryan Brown \\ Kerwin Kofi Charles \\ Daniel I. Rees \\ Working Paper 22456 \\ http://www.nber.org/papers/w22456
NATIONAL BUREAU OF ECONOMIC RESEARCH
1050 Massachusetts Avenue
Cambridge, MA 02138
July 2016

The views expressed herein are those of the authors and do not necessarily reflect the views of the National Bureau of Economic Research.

NBER working papers are circulated for discussion and comment purposes. They have not been peer-reviewed or been subject to the review by the NBER Board of Directors that accompanies official NBER publications.

(C) 2016 by D. Mark Anderson, Ryan Brown, Kerwin Kofi Charles, and Daniel I. Rees. All rights reserved. Short sections of text, not to exceed two paragraphs, may be quoted without explicit permission provided that full credit, including $\odot$ notice, is given to the source. 
The Effect of Occupational Licensing on Consumer Welfare: Early Midwifery Laws and Maternal Mortality

D. Mark Anderson, Ryan Brown, Kerwin Kofi Charles, and Daniel I. Rees

NBER Working Paper No. 22456

July 2016

JEL No. I18,J08

\begin{abstract}
Occupational licensing is intended to protect consumers. Whether it does so is an important, but unanswered, question. Exploiting variation across states and municipalities in the timing and details of midwifery laws introduced during the period 1900-1940, and using a rich data set that we assembled from primary sources, we find that requiring midwives to be licensed reduced maternal mortality by 6 to 7 percent. In addition, we find that requiring midwives to be licensed may have had led to modest reductions in nonwhite infant mortality and mortality among children under the age of 2 from diarrhea. These estimates provide the first econometric evidence of which we are aware on the relationship between licensure and consumer safety, and are directly relevant to ongoing policy debates both in the United States and in the developing world surrounding the merits of licensing midwives.
\end{abstract}

\author{
D. Mark Anderson \\ Department of Agricultural Economics \\ and Economics \\ Montana State University \\ Bozeman, MT 59717-2920 \\ dwight.anderson@montana.edu \\ Ryan Brown \\ University of Colorado Denver \\ Department of Economics \\ 1380 Lawrence Street \\ Denver, CO 80217 \\ ryan.p.brown@ucdenver.edu
}

\author{
Kerwin Kofi Charles \\ Harris School of Public Policy \\ University of Chicago \\ 1155 East 60th Street \\ Chicago, IL 60637 \\ and NBER \\ kcharles@uchicago.edu \\ Daniel I. Rees \\ University of Colorado Denver \\ Department of Economics \\ Campus Box 181 \\ P.O. Box 173364 \\ Denver, CO 80217-3364 \\ Daniel.Rees@ucdenver.edu
}




\section{INTRODUCTION}

Requirements that workers hold an occupational license as a condition of employment have become increasingly common in recent decades. Indeed, the fraction of licensed workers today is nearly three times larger than the roughly 11 percent of workers in labor unions (Gittleman and Kleiner 2016). Despite the rapid growth in the prevalence of licensure requirements, there has been relatively little empirical work assessing their effects, with the bulk of studies focusing on the outcomes of licensees as opposed to the outcomes of consumers served by these workers. ${ }^{1}$

Whether consumers are helped or hurt by occupational licensure is theoretically ambiguous. Licensure has historically been justified on the grounds that requiring licensees to, for instance, pass an exam or receive formal training should push low-quality providers out of the market and raise the quality of those who remain, both of which should improve the health and safety of consumers (Shapiro 1986, Kleiner 2000, Gittleman and Kleiner 2016). On the other hand, theory suggests possible adverse consequences of licensure that could counteract, and possibly even override, the benefits to consumers from improved provider quality. Perhaps the most important among these is the possibility that licensure could lead to higher prices and reduced access to the service in question, causing consumers to substitute towards cheaper, inferior alternatives (Shepard 1978; Adams et al. 2003; Kleiner and Kudrle 2000; Kleiner et al. 2014). Moreover, because licensees are insulated from competitive pressure, their incentive to provide high-quality service may be diminished, and they may even engage in behavior that strictly lowers quality. ${ }^{2}$

\footnotetext{
${ }^{1}$ A number of papers have shown, across a variety of sectors, that persons holding occupational licenses have higher earnings (Kleiner and Kudrle 2000; Timmons and Thornten 2008; Kleiner and Krueger 2010; Kleiner and Krueger 2013; Thornten and Timmons 2013; Kleiner et al. 2014). Carroll and Gaston (1981) and Kleiner and Kudrle (2000) assessed the effects of licensing restrictions for dentists on measures of dental health. Larsen (2015) and Sass (2015) studied the relationship between teacher licensure and student achievement. See Kleiner (2015) for an excellent review of the literature.

${ }^{2}$ Carrol and Gaston (1979) suggested several mechanisms through which licensing could negatively impact quality in health care, including self-substitution towards inferior products or services, reduction in the time spent with each
} 
Not only is theory ambiguous about how licensure should affect consumer health and safety, but there is very little previous empirical work on this question. A reason for this paucity of research may be that outcomes in the modern health care system generally depend upon the actions of a host of specialists, making it difficult for researchers to convincingly disentangle how health is casually affected by licensing standards that pertain to one specific type of specialist. Establishing the causal relationship between licensing the providers of a particular medical service and consumer health would seem to require a tight link between the actions of these providers and the particular health outcome being measured.

In this study, we examine how the adoption of state midwifery licensing requirements in the early $20^{\text {th }}$ century affected the likelihood of dying from complications of pregnancy and childbirth among American women. In our view, this historical episode represents a unique natural experiment that can be leveraged to document the causal effect of licensing on health. Unlike today, American women in the early $20^{\text {th }}$ century typically gave birth at home, where they were attended by a single health care provider, either a doctor or midwife, who had sole responsibility for the health of the mother and infant (Leavitt 1983). By drawing upon historical data, we are able to estimate the relationship between requiring that a group of health care providers (midwives) be licensed and a specific consumer health outcome (maternal mortality) over which they had a direct, immediate and profound impact.

Another advantage of examining the early adoption of state licensing requirements for midwives is that, before their adoption, the market for midwifery services was wholly unregulated. By contrast, in the modern health care sector, where a large number of specialists are already licensed, loosening or tightening licensing requirements for a specific type of health care provider

customer (e.g., briefer office visits) and location choices more in line with provider preferences than consumer needs (e.g., doctor shortages in rural areas). 
represents only an incremental change in the overall licensing regime. The effect of this incremental change might be quite different from the effect of going from an unregulated market to requiring all providers to pass an exam or receive formal training. Thus, the adoption of midwifery laws in the early $20^{\text {th }}$ century represents an opportunity to explore what happens when licensing requirements are first imposed in a context where nothing of their kind had existed previously.

Our analysis uses data from 1900-1940, a period when 22 states, and at least a dozen municipalities, adopted midwifery licensing requirements. Drawing on various primary sources, we assembled information on these requirements, including their dates of passage and key provisions, which varied dramatically across states. For instance, applicants for licenses in Mississippi were judged based on their character, cleanliness and intelligence, but were not required to take an exam or graduate from a school of midwifery. By contrast, midwives in California, Washington and Wisconsin were required to graduate from a recognized school of midwifery and to pass an examination administered by their State Board of Medical Examiners. By exploiting geographical and temporal variation in the adoption of requirements such as these, we are able to assess their impact on maternal mortality. In addition, we are able to explore their effects on infant mortality as well as mortality among children under the age of 2 due to diarrhea.

Our main data source is Mortality Statistics, published on an annual basis by the U.S. Census Bureau. It contains mortality counts by cause at the state level for the period 1900-1940. Using these counts, we estimate a series of models that relate maternal mortality in a particular state and year to whether midwives were required to be licensed in order to practice. The models control flexibly for state and year effects; mortality from non-pulmonary tuberculosis and typhoid serve as proxies for milk and water quality (Clay et al. 2014). Because Mortality Statistics provides mortality counts by cause at the municipal level for the period 1900-1917, we are also able to estimate similar models that exploit the adoption of local ordinances requiring midwives to be licensed. 
We find that the introduction of licensing requirements for midwives was associated with a 6 to 7 percent reduction in maternal mortality. This result is robust across a variety of specifications, including controlling for state-specific linear time trends. Because state and local initiatives to combat various infectious diseases could have been correlated with the adoption of midwifery laws and maternal mortality, we conduct several falsification tests. Specifically, we test whether midwifery laws were related to mortality from pulmonary tuberculosis, influenza, malaria and diabetes. The results provide additional evidence that the relationship between midwifery licensing requirements and maternal mortality is causal. Finally, we turn our attention to infant, as opposed to maternal, mortality. We find that requiring a license in order to practice midwifery is associated with reductions in nonwhite infant mortality and mortality among children under the age of 2 from diarrhea, although we argue that these results should be viewed as more tentative than the maternal mortality results described above.

Our results are directly relevant to ongoing policy debates. One set of debates have to do with the modern practice of midwifery in the United States, where there are, broadly speaking, two types of midwives. Nurse midwives, who typically work in hospitals, are required to be licensed. In contrast, "lay" or "direct-entry" midwives typically attend births that occur outside of the hospital most commonly at home. Licensure rules for lay midwives differ dramatically across states. In some states, lay midwives are required to meet specific conditions in order to obtain a license and practice, while in other states they are essentially unregulated (Rooks 1997; Rausch 2008; Reaves 2010; Rini 2015). Over the course of the last decade, the number of women choosing to deliver outside of hospitals has increased sharply (Belluck 2015), raising questions as to whether the presence or stringency of licensing rules for lay midwives affect maternal health outcomes. Although our estimates are from an earlier period in U.S. history, we are aware of no other evidence on this issue. 
Given the levels of health, medical technology and wealth that prevailed in the United States during the time period we study, our results may be even more relevant to ongoing policy debates about the merits of training and licensing midwives in developing countries today, where maternal mortality rates are often comparable to U.S. rates at the turn of the $20^{\text {th }}$ century. ${ }^{3}$ In many developing nations, the majority of births are attended by traditional birth attendants (TBAs), who have no formal education or training. ${ }^{4}$ Experts have claimed that replacing TBAs with trained and licensed midwives would substantially reduce infant and maternal mortality (WHO 2005 pp. 68-72; Thompson et al. 2011; UNFPA 2011 pp. 2-7). This claim is based, in large part, on historical studies showing that Sweden had a lower maternal mortality rate than a handful of other industrialized countries (including the United States) during a period lasting roughly from when its municipalities were first required to employ a trained midwife in the early $19^{\text {th }}$ century until 1940 (De Brouwere et al. 1998; Adegoke and van den Broek 2009; Loudon 2000a; UNFPA 2011). However, these studies do not isolate the effect of Sweden's midwifery requirements from other potentially important influences. ${ }^{5}$ Moreover, the credibility of cross-country comparisons is severely limited by the fact that in the late 1800s (when the first midwife laws were introduced in the United States) through the early 1900s, maternal mortality was not coded in a uniform fashion across countries (Loudon 1999). Our results and methods contribute credible evidence to this important policy issue.

The remainder of the paper is organized as follows. We begin with a historical overview of the midwifery debate and laws in the United States at the turn of the $20^{\text {th }}$ century. In Section 3 , we

\footnotetext{
${ }^{3}$ At the turn of the $20^{\text {th }}$ century, the U.S. maternal mortality ratio (MMR, maternal deaths per 100,000 live births) was approximately 700 (Woodbury 1924; Loudon 2000a, 2000b). In comparison, the MMR in Sub-Saharan Africa today is estimated to be between 380 and 730 (WHO 2014).

${ }^{4}$ See United Nations Population Fund Report (UNFPA 2011).

5 Two such potential influences were the introduction of anti-septic technology and better nutrition (Högberg et al. 1986; Tomkins 2001).
} 
describe our empirical approach; in Sections 4 and 5 we report the principal maternal mortality results based on state- and municipal-level data, respectively. In Section 6, we explore the effect of midwifery laws on infant mortality, and in Section 7 we examine midwifery laws and the supply of midwives. Section 8 concludes.

\section{Historical Overview}

In the mid-1800s, the field of obstetrics was in its infancy and the vast majority of births in the United States were attended by midwives without formal training (Leavitt 1983; Drife 2002). As obstetrical knowledge and practices advanced, middle- and upper-class women increasingly relied on doctors to deliver their babies. By the turn of the $20^{\text {th }}$ century, doctors attended roughly half of U.S. births (Jacobson 1956). ${ }^{6}$

This emerging preference for doctors as birth attendants can be attributed, at least in part, to the widespread perception that they were more competent than midwives (Rooks 1997, pp. 22-23). There is, however, reason to believe that women's trust in doctors was misplaced.

In general, midwives were loath to intervene in the birthing process (Leavitt 1983). In contrast, many doctors in the early 1900s routinely used forceps and anesthesia (ether or chloroform) during delivery. Being trained in the use of forceps was an important advantage if the labor was prolonged or the baby was in breech position, but the overuse of forceps came with significant risks to the mother and child. The leading cause of maternal mortality at the turn of the $20^{\text {th }}$ century was “childbed” or puerperal fever (Loudon 2000a). ${ }^{7}$ According to Leavitt (1983, p. 292):

\footnotetext{
${ }^{6}$ According to Leavitt (1983, p. 295), "Most of these births took place in the woman's home." By 1933, approximately one-third of all births took place in the hospital (Leavitt 1983, p. 301).

7 Puerperal fever, an infection of the reproductive tract during labor or its aftermath, was typically caused by Group A streptococcus bacteria (Nathan and Leveno 1994; De Costa 2002). Described as "the classic example of iatrogenic
} 
Inappropriate forceps use and the careless administration of ether and chloroform introduced serious lacerations and breathing disorders that otherwise might not have developed. Most significant, physicians carried puerperal fever, which was potentially disastrous, to birthing women. Because their medical practices included attending patients with communicable diseases, doctors were more likely than midwives to bring with them on their hands and on their clothing the agents of infection.

In fact, contemporary studies provide strong evidence that mortality rates were higher among mothers attended by a doctor than among mothers attended by a trained midwife (Jacobi 1912; Mendenhall 1917; Levy 1918, 1923; Sobel 1918). Despite this evidence, doctors and public health officials argued forcefully that midwives were to blame for puerperal fevers (Cody 1913; Plecker 1915; Edgar 1916; Frizzelle 1917; Terry 1917; Stedman 1920; Howe 1921; Rude 1922), and a variety of solutions to the so-called "midwife problem" were proposed. The abolition of midwifery was prominent among these solutions (Emmons and Huntington 1912; Williams 1912; Huntington 1913; De Lee 1915; Holmes 1920). However, some physicians conceded that abolition was impractical and, as an alternative, recommended the licensing and increased supervision of midwives coupled with teaching antiseptic technique and how to recognize pregnancy complications (Edgar 1916; Hardin 1925).

Midwives, many of whom were black or foreign-born, lacked the political and social clout to effectively counter the physician-led campaign against them (Rooks 1997, p. 24), and the demand for midwifery services continued to fall. ${ }^{8}$ By 1935, only 11 percent of births in the United States were

disease--that is, a disease caused by medical treatment itself' (Wertz and Wertz 1977, p. 128), puerperal fever accounted for about half of all deaths related to childbirth at the turn of the $20^{\text {th }}$ century; only tuberculosis killed more women of childbearing age in the United States (Woodbury 1924; Loudon 2000a, 2000b). In our sample, which covers the period 1900-1940, 38 percent of maternal mortality was due to puerperal fever.

${ }^{8}$ Information on the race and national origin of midwives is available from a variety of contemporary sources. Crowell (1907) surveyed 500 midwives practicing in New York City; 96 percent were foreign born and 30 percent were "unable to speak English." Koehler and Drake (1911, p. 25) estimated that, of the 485 midwives practicing in Chicago, "35 per cent are Slavic and 6 per cent are Italian.” Jeidell and Fricke (1912) surveyed 119 midwives living in Anne Arundel County, Maryland. Of these, 95 were identified as "Negroes", 17 were identified as "Americans" and the remainder were identified as foreign born. Thirty-four had registered with the Board of Health and only 21 were licensed to practice midwifery. According to Williams (1915), 326 midwifery licenses were issued by the State of New York 
attended by midwives; of these, 63 percent were to nonwhite mothers (Jacobson 1956, p. 254). By 1940, the last year of our analysis, 9 percent of births were attended by midwives; of these, 68 percent were to nonwhite mothers (Jacobson 1956, p. 254).

\subsection{EARLY MidWifERY LAWS}

The practice of midwifery was wholly unregulated in the United States until 1877, when Illinois became the first state to require licensure (Rooks 1997, pp. 17-22; Sandvick 2009). Under the Illinois Medical Practice Act, licensure was required of any person "practicing medicine, in any of its departments." Licenses were issued by the newly created State Board of Health, which was empowered to give examinations to practitioners who had not graduated from a recognized medical institution. ${ }^{9}$ Although midwifery was nowhere mentioned in the Act, the Board of Health contended that it made "the same requirement of midwives as of physicians" (Illinois State Board of Health 1879 , p. 54).

The Illinois Medical Practice Act of 1877 served as a model for other state legislatures interested in regulating the practice of medicine (Sandvick 2009). By the turn of the $20^{\text {th }}$ century, most states required physicians to be licensed (Hamowy 1979), but only 8 states (Connecticut, Illinois, Indiana, Louisiana, Minnesota, New Jersey, Ohio and Wyoming) required midwives to be licensed. ${ }^{10}$ Under increasing pressure from public health officials and members of the medical

between November 16, 1914 and April 15, 1915. Eight of the licensed midwives were identified as “American”, 1 was identified as "Colored" and the remaining midwives were identified as foreign born (Williams 1915). The Texas Bureau of Child Hygiene (1925) provided background information on 485 midwives practicing in 6 Texas counties. Of these, 76 percent were identified as "Colored", 18 percent were identified as "Mexican" and 6 percent were identified as either "White" or "American." Finally, according to Smith (2005, p. 62), by "the mid-1920s the state [of Washington] had licensed... at least 40 Japanese midwives out of a total of 60 midwives."

9 One year after the Act came into effect, the State Board of Health estimated that no fewer than 1,400 "non-graduates" had been forced out of the state for practicing medicine without a license (Illinois State Board of Health 1879, p. 5).

${ }^{10}$ In addition to requiring a license to practice, New Jersey prohibited midwives from attending breech births and administering any type of medicine or drugs; Ohio not only prohibited midwives from attending breech births, but also 
profession to address the "midwife problem" (Kobrin 1966; Rooks 1997, p. 23), 16 states passed

laws requiring the licensure of midwives between 1900 and 1920 (see Figure 1 and Appendix Table

1). Cities and towns also took up the cause. During this same period, at least 12 municipalities

(including Los Angeles and New York City) adopted ordinances requiring practicing midwives to

obtain a license, certificate or permit. North Carolina, which did not require licensure until 1935,

nonetheless required midwives to wash their hands before touching a patient and banned women

who were addicted to drugs or alcohol from the practice of midwifery (van Blarcom 1913).

Licensing requirements varied considerably across states. For instance, applicants in

Mississippi did not have to take an exam or graduate from a school of midwifery. Instead, they were

judged based on their character, cleanliness, intelligence, and "reputation for calling a doctor in

difficult or abnormal cases" (Mississippi Board of Health 1921). ${ }^{11}$ In contrast, states such as

California, Washington and Wisconsin required applicants to graduate from a recognized school of

midwifery and to pass an examination administered by their State Board of Medical Examiners

(Wisconsin 1909; Washington 1919; Henning and Hyatt 1921). ${ }^{12}$

forbade the use of instruments such as forceps. In 1896, midwives in the District of Columbia were required to pass an exam administered by the board of medical supervisors.

11 Although Texas required that midwives be of "good moral character" and graduates of a "bon fide, reputable" medical school, the law did "not apply to those who do not follow obstetrics as a profession, and who do not advertise themselves as obstetricians or midwives" (Texas 1916). Likewise, women in Missouri who did not practice midwifery as a profession and did not charge for their services were not required to obtain a license (Missouri 1909). Utah required anyone practicing obstetrics to obtain a license, but permitted the practice of obstetrics "in case of emergency" and in communities "where there are no licensed practitioners" (Egan 1910).

12 Midwives practicing in New York were perhaps subject to the most stringent licensing requirements in the country. As of 1907, midwives practicing in New York City were required to attend at least 20 deliveries under the supervision of a physician (New York Department of Health 1909). In addition, applicants had to be 21 years of age, of "moral character", able to read and write and "show evidences... of habits of cleanliness." The homes and equipment of midwives had to be available for inspection "at all times." As of 1914, the New York City Board of Health required applicants to graduate from a registered school of midwifery (New York Bureau of Child Hygiene 1915). Under a state law passed in 1913, midwives practicing outside of New York City and Rochester had to show evidence of "habits of cleanliness" and had to graduate from a recognized midwifery program or receive instruction from a physician in at least 15 deliveries (New York Department of Health 1915; Williams 1915). Because over half of its residents lived in New York City, we coded New York as requiring midwives to be licensed as of 1907. 


\section{DATA AND EMPIRICAL FrameWORK}

The U.S. Census Bureau began publication of Mortality Statistics in 1900. The initial issue contained mortality counts by cause, age and sex for 10 registration states. Mortality counts from additional registration states became available over time, and, by 1933, mortality counts from all 48 states were available (see Appendix Table 2). For our primary analysis, we digitized maternal mortality counts by state and year for the period 1900-1940. We also digitized maternal mortality counts by urbanicity and by cause (puerperal fever versus other causes), infant mortality counts by race, and mortality counts for diabetes, influenza, malaria, tuberculosis (pulmonary and nonpulmonary) and typhoid.

As described above, the effect of midwifery laws on maternal mortality is, a priori, ambiguous. Licensing requirements could have stimulated the formation of human capital and prevented the least competent midwives from practicing (Shapiro 1986). However, by restricting supply and insulating midwives from competition, midwifery laws could have reduced the quality of services provided (Carroll and Gaston. 1979). For instance, if licensed midwives attended more births than their unlicensed counterparts (or intervened more often in an effort to hasten delivery), then their clients would have been at greater risk of puerperal fever.

Figure 2 compares pre- and post-licensing maternal mortality trends. The solid line represents the average maternal mortality rate per 100,000 females for the treated states (i.e., those that passed a midwifery law at some point during the period 1900-1940). The dashed line represents the average maternal mortality rate for a set of control states (i.e., those in which midwifery was unregulated during the period 1900-1940). Year 0 on the horizontal axis represents the year in

which a midwifery law was passed and mortality rates are expressed relative to Year -1 . Control states were randomly assigned Year 0 . 
Maternal mortality begins a clear downward trend in the treated states immediately following the adoption of licensing requirements. In the control states, maternal mortality is essentially flat after Year 0. Moreover, there is no evidence that maternal mortality trends were different in the treated versus control states prior to the adoption of licensing requirements, suggesting that midwifery laws were not systematically preceded by, for instance, other state initiatives aimed at improving maternal health.

To further explore how early midwifery laws affected maternal mortality, we estimate the following baseline regression:

$$
\ln (\text { Maternal Mortalityst })=\beta_{0}+\beta_{1} \text { Midwifery License Required } d_{s t}+\boldsymbol{X}_{s t} \beta_{2}+v_{s}+w_{t}+\varepsilon_{s h}
$$

where $s$ indexes states and $t$ indexes years. Our independent variable of interest, Midwifery License Required, is equal to one if midwives in state $s$ were required by state law to be licensed in year $t$. The coefficient $\beta_{1}$ is our parameter of interest. It is the combined effect of the various mechanisms by which a state's decision to require occupational licensing for midwives affected maternal mortality, including any effect operating through increased human capital among providers, changes in the price charged by (or ease of access to) providers, and any switching to cheaper, inferior providers. We measure maternal mortality as deaths due to complications from pregnancy or childbirth per 100,000 female population. ${ }^{13}$ More specifically, maternal mortality counts included women in the "puerperal state", which lasted through pregnancy and continued for 42 days after delivery (Guyer et

\footnotetext{
${ }^{13}$ Maternal mortality rates are typically measured per live births (Thomasson and Treber 2008; Jayachandran et al. 2010), but information on births at the state-year level is unavailable until 1915 (Linder and Grove 1947). Using information on live births for the period 1915-1940, we calculated the correlation between maternal mortality per 100,000 female population and maternal mortality per 100,000 live births to be .83 . We also experimented with using the maternal mortality rate per 100,000 females aged $15-45$. These results were very similar to those reported below.
} 
al. 2000). Women who died from infectious diseases during the puerperal state were included in these counts (Loudon 1999).

The controls, represented by the vector $\boldsymbol{X}$, are listed in Table 1, along with descriptive statistics and definitions. They include state-level demographic characteristics $(\%$ Pop $<18, \%$ Pop 18 65, \% White, \% Black, \% Urban, \% Female, \% Foreign, Physicians per Capita), which are from the Census and estimated using linear interpolation for intercensal years. Policy controls include Physician Diploma, an indicator for whether the state required a diploma to practice medicine, and Physician Education, an indicator for whether medical boards were empowered to set pre-professional education standards. ${ }^{14}$ We also include a department of child hygiene indicator, a women's suffrage indicator and Sheppard-Towner Act spending for the period 1922-1929. Miller (2008) found that allowing women to vote led to substantial increases in public health spending by municipalities and an 8 to 15 percent reduction in child mortality. The Sheppard-Towner Act, passed in 1921, funded the training of midwives and the establishment of health care clinics; public health nurses used Sheppard-Towner funds to visit new and expectant mothers (Moehling and Thomasson 2014). ${ }^{15}$

The terms $v$ and $w$ represent state and year fixed effects, respectively. The state fixed effects, $v$, control for state-level determinants of maternal mortality that are constant over time; the year fixed effects, $w$, control for nation-wide shocks to maternal mortality due to, for instance, innovations in medical technology. ${ }^{16}$

\footnotetext{
${ }^{14}$ Information on educational requirements for physicians is from Hamowy (1978). As shown in Table 1, most of the variation in these laws occurred before 1900.

${ }^{15}$ Information on the establishment of departments of child hygiene and when suffrage was granted to women is from Moehling and Thomasson (2012). Data on Sheppard-Towner spending are from the U.S. Children's Bureau (1931). Moehling and Thomasson (2012) argued that prior establishment of a department of child hygiene may have explained variation in state participation in Sheppard-Towner.

${ }^{16}$ One such innovation was the widespread adoption of sulfa drugs in 1937, which had the effect of dramatically reducing maternal mortality (Jayachandran et al. 2010). This period also saw a shift in childbirth from the home to the hospital. At the end of the $19^{\text {th }}$ century, only homeless women or those who could not receive in-home assistance delivered in hospitals (Leavitt 1986). As the $20^{\text {th }}$ century progressed, childbirth in hospitals became commonplace. By 1940, over half of births in the United States took place in the hospital (Leavitt 1986). Thomasson and Treber (2008)
} 
Next, following Clay et al. (2014), we augment the baseline estimating equation by including mortality from typhoid as a proxy for water quality and mortality from non-pulmonary tuberculosis as a proxy for milk quality. Water quality was an important determinant of health at the turn of the $20^{\text {th }}$ century (Cutler and Miller 2004; Alsan and Goldin 2015). Local and state policies aimed at improving milk quality were introduced in response to alarmingly high rates of infant mortality (Wolf 2003), but adult mortality due to non-pulmonary (e.g., bovine) tuberculosis was not inconsequential (Olmstead and Rhode 2004a, 2004b). The augmented estimating equation is:

$$
\begin{aligned}
& \ln (\text { Maternal Mortalityst })=\beta_{0}+\beta_{1} \text { Midwifery License Required } d_{s t}+\boldsymbol{X}_{s t} \beta_{2}+\beta_{3} \text { Typhoid }_{s t} \\
& +\beta_{4} \text { Non-Pulmonary TB } B_{s t}+v_{s}+w_{t}+\varepsilon_{s t}
\end{aligned}
$$

where Typhoid is equal to mortality due to typhoid per 100,000 population and Non-Pulmonary TB is equal to mortality due to non-pulmonary tuberculosis per 100,000 population.

Finally, we include state-specific linear time trends $\left(\Theta_{s} \cdot t\right)$ to account for the possibility that mortality rates evolved at different rates in states that adopted licensing requirements as compared to states that did not:

$$
\begin{aligned}
& \ln \left(\text { Maternal Mortality }_{s t}\right)=\beta_{0}+\beta_{1} \text { Midwifery License Required } \text { L }_{s t}+\boldsymbol{X}_{s t} \beta_{2}+\beta_{3} \text { Typhoid }_{s t} \\
& +\beta_{4} \text { Non-Pulmonary TB } \text { S }_{s t}+v_{s}+w_{t}+\Theta_{s} \cdot t+\varepsilon_{s t}
\end{aligned}
$$

The actual effect of midwifery laws on maternal mortality is an empirical question, to which we now turn our attention.

concluded that this shift in where deliveries occurred did not lead to a reduction in maternal mortality until the widespread adoption of sulfa drugs. 


\section{Results Based on State-Level Data, 1900-1940}

Estimates of $\beta_{1}$ using annual data for the period 1900-1940 are presented in Table 2. The regressions are weighted by the female population of state $s$ in year $t$, and the standard errors are corrected for clustering at the state level (Bertrand et al. 2004). During the period under study, 22 states required midwives to be licensed. Pre- and post-treatment mortality data were available for 18 of these states. Figure 1 shows when each midwifery law was adopted and Appendix Table 1 provides a brief description of these laws as well as our sources, most of which are contemporary. ${ }^{17}$

The estimate of $\beta_{1}$ reported in the first column of Table 2 is from a model that only controls for state-level demographic characteristics, state fixed effects and year fixed. It suggests that the licensing of midwives leads to a $6.0\left(\mathrm{e}^{-.062}-1=-.06\right)$ percent reduction in maternal mortality, or roughly 1.7 fewer deaths per 100,000 women relative to a mean of 27.9. Controlling for whether women had the right to vote in state $s$ and year $t$, Sheppard-Towner spending and the other policies listed in Table 1 has a negligible impact on this estimate. Likewise, controlling for mortality from typhoid and mortality from non-pulmonary tuberculosis (our proxies for water and milk quality, respectively), has very little impact on the estimated relationship between licensing and maternal mortality. Although we do not observe every public health initiative at the state and/or local level that may have affected maternal mortality, and therefore cannot account for their influence, the remarkable stability of the estimates reported in Table 2 is reassuring. ${ }^{18}$

\footnotetext{
${ }^{17}$ Appendix Table 2 lists the years of data available for each of the states used in the analysis.

${ }^{18}$ Miller (2008) showed that the passage of women's suffrage laws led to substantial increases in public health spending at the municipal level on charities, corrections and hospitals. Although this spending was negatively and significantly related to infant mortality from infectious diseases, it was essentially unrelated to maternal mortality (Miller 2008, p. 1310). Other local public health initiatives undertaken during this period were mostly aimed at reducing infant, as opposed to maternal, mortality (Kotelchuck 2007, p. 108). For instance, the Chicago Health Department sent nurses into neighborhoods with the highest infant mortality rates to promote breastfeeding; in Minneapolis, public health workers helped new mothers with lactation-related problems (Wolf 2003). The Sheppard-Towner Act funded a wide variety of public health initiatives at the local and state level that could have potentially affected maternal mortality. Moehling and Thomasson (2014) found that Sheppard-Towner spending was negatively related to infant mortality, but did not examine its relationship to maternal mortality.
} 
In column (4), we control for state-specific linear time trends. Their introduction has no effect on the magnitude of our estimate of $\beta_{1}$, which remains statistically significant at the 5 percent level. In the final column of Table 2 , we test the parallel trends assumption by adding a lead to the model, equal to 1 if a midwifery law was passed in year $t+1$, and equal to 0 otherwise. The estimated coefficient of the lead, although negative, is small and not statistically significant.

\subsection{FAlsification Tests}

Until the 1920s, public health officials focused their efforts on reducing infant, as opposed to maternal, mortality (Kotelchuck 2007, p. 108). However, state and local initiatives to combat tuberculosis and other infectious diseases (such as influenza and malaria) could have been correlated with the adoption of midwifery laws, potentially biasing our estimates of their effects on maternal mortality. ${ }^{19}$ Such initiatives included the application of insecticides and other methods of pest control (Kitron and Spielman 1989), waste management (Centers for Disease Control and Prevention 1999), forming local and state anti-tuberculosis associations (Knopf 1922) and passing anti-spitting laws (O’Conner 2015).

We address this potential issue by conducting a series of falsification tests. Specifically, we examine the relationship between midwifery laws and mortality due to the following causes: pulmonary tuberculosis, influenza, malaria and diabetes.

The results of these falsification tests are reported in Table $3 .^{20}$ If state-specific linear trends are not included, requiring midwives to be licensed is associated with a statistically significant increase

\footnotetext{
${ }^{19}$ As noted above, during the period under study, many states used a broad definition of maternal mortality that included women who died in pregnancy, during labor and up to 42 days after delivery due to infectious diseases such as influenza and tuberculosis (Loudon 1999). Almond (2006), in fact, used maternal mortality to measure the intensity of the 1918 influenza epidemic.

20 Mortality rates are logged except in the case of malaria, which was equal to zero for a number of states and years. Instead of taking the natural log of mortality due to malaria, we take its quartic root. This method of dealing with zeros
} 
in mortality due to diabetes. When the state-specific trends are included, all of the estimated coefficients of the midwifery law indicator are positive, but insignificant. This pattern of results suggests that the adoption of midwifery licensing requirements was not related to maternal health through public health initiatives aimed at combating tuberculosis and other infectious diseases.

\subsection{Heterogeneous EfFects}

In 8 of the 18 states for which we have pre- and post-treatment maternal mortality data, a license could be obtained by receiving basic instruction from a public health nurse or county health officer. $^{21}$ Five states required applicants to pass an examination, typically administered by the State Board of Health, and 5 required applicants to graduate from a recognized school of midwifery. ${ }^{22}$ We begin by estimating the fully saturated model, allowing the effect of midwifery laws to differ based on these basic classifications.

The results, which are reported in the first column of Table 4, suggest that adopting even the most basic licensing requirements led to a small (3.5 percent) reduction in maternal mortality. We also find evidence that the relationship between midwifery laws and maternal mortality was more pronounced in states that required applicants to pass an exam or graduate from a recognized school of midwifery. However, these estimates are not precisely measured. In fact, we cannot formally

\footnotetext{
has been used by Thomas et al. (2006), Tarozzi et al. (2014) and Ashraf et al. (2015), among others. Marginal effects are reported in brackets. Defining the dependent variable as $\ln (1+$ Malaria $)$ yielded similar results.

${ }^{21}$ Specifically, these states were DE, GA, KY, MS, NC, SC, VA and WV.

${ }^{22}$ We observe maternal mortality in CO, MD, NM, PA and RI before and after midwives were required to pass an exam. We observe maternal mortality in CA, FL, NY, WA and WI before and after midwives were required to graduate from a recognized school of midwifery. We include Florida in this third category despite the fact that applicants had the option of attending 15 deliveries under the supervision of a physician in lieu of graduating from a recognized school of midwifery (Hanson 1931). Likewise, we include New York in this category despite the fact that New York City did not require applicants to graduate from a registered school of midwifery until April 1, 1914 (New York Department of Health 1915), and applicants outside of New York City and Rochester had the option of receiving instruction in at least 15 deliveries from a physician in lieu of graduating from a recognized school of midwifery (Williams 1915).
} 
reject the hypothesis that all three types of midwifery laws had comparable effects on maternal mortality.

In the second and third columns of Table 4, we focus on urban versus rural status.

Specifically, urban mothers are defined as those who lived in a city or town with a population greater than $10,000 .^{23}$ Maternal mortality was substantially higher among these women than among their rural counterparts (17.7 per 100,000 population versus 11.6), but enforcement of midwifery laws was, by many accounts, much stricter in urban areas (Borst 1995, pp. 55-60; Molina 2006, p. 105). Consistent with these accounts, the results suggest that the relationship between licensing and maternal mortality was strongest in urban areas. In fact, although negative, the estimated coefficient of Midwifery License Required is not statically significant when our attention is restricted to mothers living in rural areas.

In the remaining columns of Table 4, we distinguish between maternal mortality due to puerperal fever and maternal mortality from other causes (e.g., breech births, hemorrhaging, albuminuria, or infectious diseases such as tuberculosis). Requiring a license is associated with a nearly 7 percent reduction in maternal mortality due to puerperal fever, suggesting that the focus on antiseptic technique and non-intervention was effective. ${ }^{24}$ It is also associated with a 5.4 percent reduction in maternal mortality from other causes, suggesting that licensed midwives could, at a minimum, identify birth complications and ask for assistance from a physician in a timely fashion. ${ }^{25}$

\footnotetext{
23 Prior to 1910, Mortality Statistics defined "urban" as cities or towns with a population greater than 8,000. The inclusion of year fixed effects should account for any effect this change in definition might have had on maternal mortality.

${ }^{24}$ Midwifery laws often required applicants to demonstrate their "cleanliness" (Williams 1915; Mississippi Board of Health 1921; Hansen 1931), while midwifery instruction and textbooks emphasized antiseptic technique and discouraged the use of forceps except in the case of emergency (Jewett and Jewett 1901; Johnstone 1913; Dodd 1920; Leavitt, 1983).

25 Some states prohibited midwives from attending breech births or twins (Egan 1910; Levy 1921), while exams and instruction emphasized recognizing birth complications in advance. For instance, licensed midwives in North Carolina were taught basic "danger signals" and when to call a physician or take a patient to the nearest clinic (Dodd 1920, p. 865). In Wisconsin, students at a prominent school of midwifery were taught "what not to do, and when to seek the aid of a practising physician" (Borst 1988, p. 617). A copy of the exam administered by the Wisconsin Medical Board of Examiners to Dora Larson, a Norwegian-born, apprentice-trained midwife, is available at:
} 


\section{Results Based on Municipal-Level Data, 1900-1917}

We turn now to an analysis of the relationship between midwifery laws and maternal mortality at the municipal level. Again, we use annual data drawn from the U.S. Census Bureau's Mortality Statistics. The initial issue contained mortality counts by cause and age for over 300 registration cities. By 1917, mortality counts from over 500 cities are available, although we restrict our attention to the 384 municipalities that contributed at least 10 years of data and had a population greater than $10,000 .^{26}$

There are several advantages to adding municipal-level results to our analysis above, which exploited state-level variation. First, 9 municipalities adopted midwifery licensing requirements during this period before the state in which they were located did, representing an alternative source of policy variation (see Appendix Table 4). Second, the municipal-level data allow us to focus on mothers living in urban areas, where the results in Table 4 suggest that the effect of midwifery laws should be most pronounced. Third, a number of cities began reporting maternal mortality counts before this information was available at the state level. For instance, Texas required midwives to be licensed in 1907, but state-level mortality counts are not available for Texas until 1933. However, municipal-level data are available for the city of Galveston for the period 1906-1917 and for San Antonio for the period 1900-1917. We report the states and years covered in the municipal-level data set in Appendix Table 5. Using municipal-level data allows us to capture policy variation for Missouri, Texas and Utah not exploited in the state-level results. A serious limitation of using

http://ebling.library.wisc.edu/historical/wi-women/exam questions.pdf. The exam consisted of 12 questions, including, "When you examine a woman in labor, how do you determine if the position is normal?" and, "What are the symptoms of kidney trouble in a pregnant woman?" We have reproduced the questions from this exam in Appendix Table 3.

${ }^{26}$ On average, each municipality contributed 17.7 observations to the analysis. Mortality Statistics provides mortality counts though 1922, but we chose to focus on the period 1900-1917 in order to avoid confounding the effect of midwifery laws with the 1918 influenza epidemic. It should be noted that the state-level results discussed above are robust to excluding the years 1918-1920. 
municipal-level data is that our models no longer include pre- and post-treatment mortality counts for 10 states (Delaware, Georgia, Kentucky, Mississippi, New Mexico, North Carolina, Rhode Island, South Carolina, Virginia and West Virginia).

We estimate municipal-level regressions similar to those used in the state-level analysis. We first estimate the municipal-level analog to equation (1), and then augment that specification by adding controls for mortality from typhoid, non-pulmonary tuberculosis and municipality-specific linear time trends. This estimating equation is thus

$$
\begin{aligned}
& \text { Maternal Mortality } m t=\beta_{0}+\beta_{1} \text { Midwifery License Required }_{m t}+\boldsymbol{X}_{m t} \beta_{2}+\beta_{3} \text { Typhoid }_{m t} \\
& +B_{4} \text { Non-Pulmonary TB }_{m t}+v_{m}+w_{t}+\Theta_{m} \cdot t+\varepsilon_{m},
\end{aligned}
$$

where $m$ indexes municipality and $t$ indexes year. Our independent variable of interest, Midwifery License Required, is equal to 1 if midwives in municipality $m$ were required by either state law or a municipal ordinance to be licensed. ${ }^{27}$ Because maternal mortality at the municipal level can be zero, we take its quartic root, which mimics the natural $\log$ function for positive numbers. ${ }^{28}$ Marginal effects are reported in brackets. This method of dealing with zeros has been used by Thomas et al. (2006), Tarozzi et al. (2014) and Ashraf et al. (2015), among others.

The results are reported in Table 5 and provide additional evidence that requiring midwives to be licensed is associated with reductions in maternal mortality. When we do not control for state-

\footnotetext{
27 The variables included in $\boldsymbol{X}$ are listed in Appendix Table 6. In addition to the policy controls used in the state-level analysis, we also control for the presence of a state public health department. We observed no variation in this policy for the state panel.

${ }^{28}$ Specifically, there are 585 observations for which Maternal Mortality is equal to zero. We also estimated a version of equation (4) in which the dependent variable was set equal to $\ln (1+$ Maternal Mortality). These estimates are qualitatively similar to those reported in Table 5. It should also be noted that Maternal Mortality for the municipal-level analysis is defined as the rate per 100,000 population, not per 100,000 females. Data on municipal populations by sex were not available.
} 
or municipality-specific linear time trends, estimates of $\beta_{1}$ in the municipal-level results are, in fact, larger than those reported in Table 2. These point estimates imply that licensing was associated with a decrease in maternal mortality of 16 to 19 percent. When state- or municipality-specific trends are added to the regressions, the estimates remain negative, albeit smaller in absolute value and no longer statistically significant at conventional levels. If taken at face value, they would suggest that licensing was associated with a decrease in maternal mortality of 4 to 6 percent, which is comparable in magnitude to the estimates based on state-level data reported in Table 2.

\section{INFANT MORTALITY}

Our analysis has thus far focused on maternal mortality. However, there are at least two reasons why licensing and training midwives could have also affected mortality among infants. First, midwifery instruction and textbooks emphasized the importance of breastfeeding. ${ }^{29}$ During the time period under study, most American mothers did not exclusively breastfeed, but instead supplemented their breast milk with cow's milk and weaned their infants within three months of birth (Wolf 2003). ${ }^{30}$ Advice from midwives could have altered these practices and affected mortality as a result. Second, licensed midwives were trained in antiseptic technique and artificial respiration, and would have been able to recognize and handle common birth complications such as breech position or a nuchal cord (Jewett and Jewett 1901; Johnstone 1913). ${ }^{31}$ The possibility that this kind of training could have reduced the number of infants dying shortly after birth during the early 1900 s

\footnotetext{
${ }^{29}$ For instance, one popular textbook for midwives unequivocally stated: "In all cases an infant should be suckled by its mother unless definite contra-indications exist" (Johnstone 1913, p. 407). See also Jewett and Jewett (1901, pp. 188-189) and Smith (2005, p. 130). It might also be noted that breastfeeding would have, in all likelihood, ceased if the mother died as a result of, for instance, puerperal fever.

${ }^{30}$ Most cities did not require cow's milk to be pasteurized until the 1920s (Brosco 1999) and, as a consequence, it was often spoiled or contaminated with bovine tuberculosis (Wolf 2003; Olmstead and Rhode 2004a).

31 A nuchal cord occurs when the umbilical cord becomes wrapped around the baby's neck.
} 
is supported by recent research in Zambia, the results of which suggest that teaching TBAs about newborn care (including training in cleanliness, resuscitation and how to diagnose birth complications) can lead to dramatic reductions in 7-day neonatal mortality due to asphyxia and infection (Carlo et al. 2010).

Table 6 presents estimates of the relationship between midwifery laws and infant mortality. The first three columns report results based on the state-level panel for the period 1900-1940, while the last six columns report results based on the municipal-level panel for the period 1900-1917. An advantage of the state-level data is that information on infant mortality by race is available for most state-year combinations. ${ }^{32}$ The estimate in the first column is small, positive and insignificant, suggesting that the licensing of midwives had no effect on the overall infant mortality rate. When we examine the relationship between midwifery laws and infant mortality by race, it appears to be strongest among nonwhites. ${ }^{33}$ Specifically, requiring a license is associated with 12.4 fewer deaths relative to a mean of 248.9 , or roughly a 5 percent reduction in the nonwhite infant mortality rate. This pattern of results is, in retrospect, not surprising. The demand for midwives appears to have been much higher among blacks than among whites throughout the period under study (Dart 1921; Cornely 1942; Jacobson 1956; Robinson 1984). ${ }^{34}$ Better training coupled with the forced retirement of incompetent midwives could have had a substantial impact on the health of black infants. ${ }^{35}$

\footnotetext{
32 With the exception of Maryland, infant mortality counts by race were not available at the state level until 1910.

${ }^{33}$ For the nonwhite infant mortality regression, we take the quartic root of the mortality rate. There are 36 observations for which Nonwhite Infant Mortality is equal to zero. We also experimented with using $\ln (1+$ Nonwhite Infant Mortality $)$ as the dependent variable. The resulting estimate was similar to the one reported in Table 6.

${ }^{34}$ Even in 1940, almost half of all births to nonwhite mothers were attended by midwives (Jacobson 1956, p. 254).

35 There is anecdotal evidence that the adoption of licensing restrictions substantially improved the quality of midwives serving black communities in the South. For instance, Dodd (1920, p. 863), the Director of Child Hygiene and Public Health Nursing, described the typical midwife practicing in South Carolina prior to the imposition of licensing requirements:
}

In South Carolina, she is usually the grandmother or grand-aunt or old friend of the family who goes in to "help out" in the emergency of child birth. When she becomes too old and too 
Next, we turn our attention to the municipal-level data. While infant mortality counts by race are not available for most registration cities, we have information on diarrhea mortality counts. ${ }^{36}$ The so-called "urban mortality penalty" at the turn of the $20^{\text {th }}$ century was due, at least in part, to diarrheal diseases (Haines 2001). In addition to encouraging breastfeeding, which helps maintain hydration, trained midwives had an effective treatment for diarrhea at their disposal (Johnstone 1913, p. 413). ${ }^{37}$

Similar to our findings from the state-level analysis, there is little evidence of a relationship between licensing and overall infant mortality in the municipal data. Licensing is, however, associated with a 3 to 10 percent reduction in the mortality among children under the age of 2 from diarrhea. ${ }^{38}$

decrepit to be of any further use of earth, she takes up midwifery. She cannot fill out a birth certificate because she cannot write her own name. She has no standards, her remuneration is negligible, and her number is legion.

After licensing was required in 1920, midwives received instruction in recognizing birth complications and "what not to do and the simple rules for ordinary cleanliness" (Dodd, 1920, p. 864). Midwives were also required to attend 4 deliveries under the supervision of a public health nurse. "If the midwife is found to be following instructions, and observing the laws of cleanliness, she will be given a midwife permit" (Dodd 1920, p. 864). According to South Carolina public health officials, the licensing of midwives had a dramatic effect on both infant and maternal mortality among blacks:

It is interesting to note that from 1919 to 1928, the last year for which we have figures tabulated separately for white and colored, there was a decided reduction in the colored rates [of death] for both infants and mothers although there was an increase in both rates for whites. This would seem to indicate that the instruction of midwives, who deliver most of the negro mothers, has not been without value to the State (South Carolina Board of Health (1932) cited in Bonaparte (2014, p. 172)).

${ }^{36}$ Deaths due to diarrhea are reported in the same category as deaths due to enteritis and are available by age group for children under the age of 2 and individuals ages 2 and over. Enteritis is inflammation of the small intestine and is generally accompanied by diarrhea.

${ }^{37}$ Huffman and Combest (1990) reviewed literature on the role of breastfeeding in the prevention and treatment of diarrhea among infants in developing countries. Johnstone's (1913, p. 413) text for midwives describes the use of albumin water to treat severe diarrhea in children. Han et al. (2009, p. 444) found that normal saline solution and albumin were equally effective for "initial hydration therapy for dehydrated term infants...due to acute diarrhea."

${ }^{38}$ For the diarrhea mortality regressions, we take the quartic root of the mortality rate. There are 31 observations for which Diarrhea Under Age 2 is equal to zero. We also experimented with setting the dependent variable equal to $\ln (1+$ Diarrhea Under Age 2). These estimates were similar to those reported in Table 6. 
We view the estimates reported in Table 6 as less definitive than the maternal mortality results reported in Tables 2-5. A wide variety of public health initiatives directed at reducing infant mortality were undertaken during the period 1900-1930 (Kotelchuck 2007). For instance, state and local educational campaigns encouraged breastfeeding (Wolf 2003); public health inspectors visited dairy farms to ensure that milk was processed under sanitary conditions and shipped in refrigerated railroad cars (Atkins 1992). If these initiatives were correlated with the adoption of midwifery laws, the results reported in Table 6 are biased estimates of the effect of licensure, as they partly capture the effect of these other policy changes occurring at the same time licensure rules were introduced. As a falsification test, we examine the relationship between midwifery laws and mortality due to diarrhea among individuals aged 2 years or older. While some (but by no means all) midwives made multiple visits to the mother and child during the first few weeks of the postpartum period (Baker 1913; Dart 1921, p. 29; Smith 2005, p. 130; Bartlett 2008, p. 21), mortality from diarrhea among individuals ages 2 and over should have been unaffected by licensing requirements but may have been affected by latent policy changes occurring at roughly the same time as licensure. Our results show that the relationship between requiring midwives to be licensed and diarrhea mortality among individuals ages 2 and over is small and statistically insignificant, suggesting that the mortality estimates for infants under 2 are unbiased. ${ }^{39}$

\section{MidwifERy LAwS AND THE Supply OF Midwives}

We conclude our analysis with an examination of the relationship between midwifery laws and the supply of midwives. From the U.S. Decennial Census data for the period 1870-1930, we can

\footnotetext{
39 The sample used to examine diarrhea mortality among individuals ages 2 and over is smaller than the sample used to examine diarrhea mortality for children under the age of 2 because the latter statistic was not consistently reported by some municipalities.
} 
obtain information on the number of women who reported that midwifery was their occupation. ${ }^{40}$

Aggregating the individual self-reports to the state level, we created a variable, Midwives, which

measures the number of women in state $s$ and year $t$ whose occupation was recorded as "midwife"

per 100,000 women ages 15-45. Presuming that these self-reports are accurate, and importantly that women who were not trained professionals did not describe themselves as "midwives", this measure can be thought of as capturing the supply of trained, professional midwives as opposed to TBAs.

There is, in fact, evidence that women without formal training, but who attended the births of family members and neighbors, did not typically consider themselves to be midwives (Borst 1988; Bickley 1990), and Census enumerators clearly undercounted women who worked on an irregular basis or at informal jobs (Lebergott 1966, pp. 153-154; Goldin 1990; Pudup 1990).

During the period under study, untrained midwives typically attended 1 or 2 births per year (Borst 1995, pp. 54-58; Barney 2000, pp. 62-65). Licensed midwives in Southern states, by contrast, attended, on average, 4 or 5 births per year, while those in Northern and Midwestern states averaged as many as 50 births per year. These numbers suggest that, if the adoption of licensing requirements prevented TBAs from practicing, even small increases in the number of licensed, professional midwives could have easily attended the births that had been handled by TBAs. ${ }^{41}$

\footnotetext{
40 Specifically, we use IPUMS one percent samples of the Decennial Censuses, housed at the Minnesota Population Center at the University of Minnesota (https://usa.ipums.org/usa/index.shtml).

41 The number of births per year attended by licensed midwives is available from a variety of contemporary sources and can be estimated based on others. For instance, during the period 1909-1920, licensed midwives in New York City attended an average of 28.2 births per year (New York City Department of Health 1921). Nicholson (1921) surveyed health departments across the country asking how many midwives were practicing in their state and what percentage of births they attended. Based on the responses to Nicholson's survey and data on births from Linder and Grove (1947), we estimated the average caseloads of licensed midwives. For instance, in Connecticut, licensed midwives attended, on average, 20.1 births per year. In Kentucky, they attended 5.4 births per year, while in Virginia they attended 4.0 births per year. Although Georgia and North Carolina did not require licensure, midwives in these states were required to register. Based on the responses to Nicholson's survey, we estimate that (unlicensed) midwives in Georgia attended, on average, 3.2 births per year. In North Carolina, they attended 3.1 births per year. In 1911, licensed midwives practicing in Providence, Rhode Island attended, on average, 49.6 births per year, while midwives in Kentucky (who were unlicensed), attended, on average, 4.1 births per year (American Association for the Study and Prevention of Infant Mortality 1913).
} 
We estimate the following equation:

$$
\text { Midwives }_{s t}=\beta_{0}+\beta_{1} \text { Midwifery License Required }{ }_{s t}+\boldsymbol{X}_{s t} \beta_{2}+v_{s}+w_{t}+\Theta_{s} \cdot t+\varepsilon_{s t}
$$

where the independent variable of interest, Midwifery License Required, is defined as before. ${ }^{42}$ Because Midwives is equal to zero in many states prior to the adoption of licensing requirements, we take the quartic root of the dependent variable and report marginal effects in brackets. ${ }^{43}$

The results, which are reported in Table 7, suggest that the adoption of licensing requirements led to a substantial increase in the supply of professional midwives. Specifically, we find that licensing is associated with an increase of 23.4 to 27.8 midwives per 100,000 women ages 15-45, relative to a mean of 22.3. Estimates of the effect of licensing requirements on the supply of foreign-born and black midwives are generally larger, but are not statistically significant at conventional levels.

\section{Conclusion}

Previous studies provide strong evidence that holders of occupational licenses earn between 11 and 18 percent more than their unlicensed counterparts, presumably because it restricts the supply of labor (Kleiner and Krueger 2010; 2013). This premium is of similar magnitude to estimates of the union-nonunion wage gap (Lewis 1986; Blanchflower and Bryson 2003). However, occupational licensing rules are rarely, if ever, portrayed by advocates as a vehicle for increasing the

\footnotetext{
42 The variables included in $\boldsymbol{X}$ are $\%$ of population less than 18 years of age, $\% 18-65$ years of age, $\%$ white, $\%$ black, $\%$ living in an urban area, $\%$ female, $\%$ foreign born, physician educational requirements, a department of health indicator, a department of child hygiene indicator, a women's suffrage indicator and Sheppard-Towner spending.

${ }^{43}$ For instance, Midwives is zero for 14 states (AZ, CO, DE, ME, MA, NE, NH, ND, RI, SD, VT, WA, WV and WY) in 1900. Of these states, only Wyoming required midwives to be licensed in order to practice.
} 
earnings of licensees. Instead, rules obligating practitioners to pass an exam, receive training, or obtain letters of reference are justified on the ground that they improve safety and public health (Kleiner 2000; Gittleman and Kleiner 2016). Yet, there is scant empirical evidence on whether this is so.

The current study draws on U.S. Census Bureau data from the period 1900-1940 to estimate the effects of midwifery licensing requirements on maternal mortality. During most of this period, puerperal fever was the leading cause of maternal mortality, accounting for approximately half of all deaths related to childbirth (Woodbury 1924; Loudon 2000a, 2000b). Doctors and public health officials argued that the unsanitary practices of midwives were to blame for the high rates of puerperal fever (Cody 1913; Plecker 1915; Edgar 1916; Frizzelle 1917; Terry 1917; Stedman 1920; Howe 1921; Rude 1922), and recommended licensing as the solution (Edgar 1916; Hardin 1925).

In response, 22 states (and at least a dozen municipalities) passed midwifery laws, bringing educational requirements and oversight to a previously unregulated market. Under these laws, a license could often be obtained by simply receiving basic instruction from a public health nurse or county health officer. In other states, applicants were required to graduate from a recognized school of midwifery and pass an examination administered by their State Board of Medical Examiners. Exploiting geographical and temporal variation in the adoption of requirements such as these, we find that the licensing of midwives led to a 6 percent reduction in maternal mortality. We also find evidence, albeit more tentative, that requiring a license reduced the nonwhite infant mortality rate. These basic results, however, mask important heterogeneity. For instance, the relationship between midwifery laws and maternal mortality appears to have been more pronounced in states that required applicants to pass an exam or graduate from a recognized school of midwifery. Moreover, this relationship was strongest in urban areas, a result that is consistent with anecdotal evidence that enforcement of midwifery laws was less strict in the countryside and small towns 
(Borst 1995, pp. 55-60; Molina 2006, p. 105). When we distinguish between maternal mortality due to puerperal fever and maternal mortality from other causes, we find that requiring a license is associated with a nearly 7 percent reduction in maternal mortality due to puerperal fever, suggesting that the focus on antiseptic technique and non-intervention was effective. Requiring a license also led to a 5 percent reduction in maternal mortality from other causes, suggesting that licensed midwives could, at a minimum, identify birth complications and when to ask for assistance from a physician.

Our results are relevant for ongoing policy debates, and also address outstanding theoretical issues. A majority of births in many developing countries are still attended by Traditional Birth Attendants (TBAs) with no formal education or training (UNFPA 2011). Experts contend that replacing TBAs with trained and licensed midwives would substantially reduce infant and maternal mortality (WHO 2005, pp. 68-72; Thompson et al. 2011; UNFPA 2011, pp. 2-7), but the evidence in support of this contention is anecdotal. In the United States, lay midwives are, in many states, required to pass an exam or graduate from an accredited program, but are essentially unregulated in others (Rooks 1997; Rausch 2008; Reaves 2010; Rini 2015).

Economic theory offers no clear guidance as to the direction of the relationship between licensing and the quality of services received by consumers (Kleiner 2000), yet licensing requirements have become commonplace in the United States and other developed countries (Gittleman and Kleiner 2016). Our results provide strong evidence that the adoption of licensing requirements between 1900 and 1940 reduced maternal mortality. To our knowledge, our study is the first to provide econometric evidence that the adoption of licensing requirements leads to an improvement in consumer health. Whether requiring doctors, dentists and other health professionals to be licensed also leads to better health outcomes is an open, but crucial, question that deserves the attention of future researchers. 


\section{REFERENCES}

Adams, A. Frank, Robert Ekelund Jr. and John Jackson. 2003. "Occupational Licensing of a Credence Good: The Regulation of Midwifery.” Southern Economic Journal, 69(3): 659-675.

Adegoke, Adetoro and Nynke van den Broek. 2009 "Skilled Birth Attendance-Lessons Learnt." BJOG: An International Journal of Obstetrics and Gynaecology, 116(s1): 33-40.

Almond, Douglas. 2006. "Is the 1918 Influenza Pandemic Over? Long-Term Effects of Influenza Exposure in the Post-1940 U.S. Population.” Journal of Political Economy, 114(4): 672-712.

Alsan, Marcella and Claudia Goldin. "Watersheds in Infant Mortality: The Role of Effective Water and Sewerage Infrastructure, 1880 to 1915.” NBER Working Paper No. 21263.

American Association for the Study and Prevention of Infant Mortality. 1913. Transactions of the Annual Meeting, Volume 3. Baltimore: Franklin Printing Company.

Ashraf, Nava, Diego Aycinena, Claudia Martinez and Dean Yang. 2015. "Savings in Transnational Households: A Field Experiment among Migrants from El Salvador." Review of Economics and Statistics, 47(2): 332-351.

Atkins, Peter. 1992. "White Poison? The Social Consequences of Milk Consumption, 1850-1930." Social History of Medicine, 5(2): 207-227.

Baker, Josephine. 1913. “The Function of the Midwife.” Women's Medical Journal, 23 (September): 196-197.

Bartlett, Marie. 2008. The Frontier Nursing Service: America's First Rural Nurse-Midwife Service and School. Jefferson, NC: McFarland and Co.

Barney, Sandra Lee. 2000. Authorized to Heal: Gender, Class, and the Transformation of Medicine in Appalachia 1880-1930. Chapel Hill: University of North Carolina Press.

Belluck, Pam. 2015. “As Home Births Grow in U.S., a New Study Examines the Risks.” New York Times, December 23. Available at:

http://www.nytimes.com/2015/12/31/health/as-home-births-grow-in-us-a-new-study-examinesthe-risks.html.

Bertrand, Marianne, Esther Duflo and Sendhil Mullainathan. 2004. "How Much Should We Trust Differences-in-Differences Estimates? Quarterly Journal of Economics, 119(1): 249-276.

Bickley, Ancella. 1990. "Midwifery in West Virginia.” West Virginia History, 49: 55-68.

Blanchflower, David and Alex Bryson. 2003. "Changes over Time in Union Relative Wage Effects in the UK and the US Revisited." In John Addison and Claus Schnabel (eds.), International Handbook of Trade Unions. Cheltenham, UK: Edward Elgar. 
Bonaparte, Alicia. 2014. "'The Satisfactory Midwife Bag': Midwifery Regulation in South Carolina, Past and Present Considerations.” Social Science History, 38(1\&2): 155-182.

Borst, Charlotte. 1988. "The Training and Practice of Midwives: A Wisconsin Study." Bulletin of the History of Medicine, 62(4): 606-627.

Borst, Charlotte G. 1995. Catching Babies: The Professionalization of Childbirth, 1870-1920. Cambridge, MA: Harvard University Press.

Brosco, Jeffrey. 1999. "The Early History of the Infant Mortality Rate in America: A Reflection Upon the Past and a Prophecy of the Future.” Pediatrics, 103(2):478-475.

Carlo, Waldemar, Elizabeth McClure, Elwyn Chomba, Hrishikesh Chakraborty, Tyler Hartwell, Hillary Harris, Ornella Lincetto and Linda Wright. 2010. "Newborn Care Training of Midwives and Neonatal and Perinatal Mortality Rates in a Developing Country." Pediatrics, 126(5): e1064-e1071. Available at: http://pediatrics.aappublications.org/content/pediatrics/126/5/e1064.full.pdf.

Carroll, Sidney and Robert Gaston. 1979. "State Occupational Licensing Provisions and Quality of Service: The Real Estate Business." Research in Law and Economics, 1: 1-13.

Carroll, Sidney L. and Robert J. Gaston. 1981. "Occupational Restrictions and the Quality of Service Received: Some Evidence.” Southern Economic Journal, 47(4): 959-976.

Centers for Disease Control and Prevention. 1999. "Achievements in Public Health, 1900-1999: Changes in the Public Health System.” Morbidity and Mortality Weekly Report, 48(50): 1141-1147.

Clay, Karen, Werner Troesken and Michael Haines. 2014. "Lead and Mortality." Review of Economics and Statistics, 96(3): 458-470.

Cody, Edmund. 1913. “The Registered Midwife: A Necessity.” Boston Medical and Surgical Journal, 168(11): 416-418.

Cornely, Paul B. "Trends in Public Health Activities among Negroes in 96 Southern Counties During the Period 1930-1939 II. Comparison of Certain Health Services Available for Negroes and White Persons." American Journal of Public Health, 32 (10): 1117-1124.

Crowell, Elisabeth. 1907. "The Midwives of New York." Charities and the Commons, 17(January): 667677.

Cutler, David and Grant Miller. 2005. "The Role of Public Health Improvements in Health Advances: The Twentieth-Century United States.” Demography, 42(1): 1-22.

Dart, Helen. 1921. Maternity and Child Care in Selected Rural Areas of Mississippi. Washington DC: Children's Bureau, U.S. Department of Labor. 
De Brouwere, Vincent, René Tonglet and Wim Van Lerberghe. 1998. "Strategies for Reducing Maternal Mortality in Developing Countries: What Can We Learn from the History of the Industrialized West?" Tropical Medicine and International Health, 3(10): 771-782.

De Costa, Caroline. 2002. "'The Contagiousness of Childbed Fever': A Short History of Puerperal Sepsis and its Treatment." Medical Journal of Australia, 177(11): 668-672.

De Lee, Joseph. 1915. "Progress towards Ideal Obstetrics." Transactions of the American Association for the Study and Prevention of Infant Mortality, 6: 114-123.

Drife, James. 2002 “The Start of Life: A History of Obstetrics.” Postgraduate Medical Journal, 78(919): 311-315.

Dodd, Ruth. 1920. "Midwife Supervision in South Carolina.” Public Health Nurse, 12(12): 863-867.

Edgar, Clifton. 1916. "The Education, Licensing, and Supervision of the Midwife." American Journal of Obstetrics and the Diseases of Women and Children, 73(March): 385-398.

Egan, James. 1910. "State Medical Licensing Boards." Medical Record: A Weekly Journal of Medicine and Surgery, 78(December): 1120-1127.

Emmons, Arthur and James Huntington. 1912. "The Midwife: Her Future in the United States." American Journal of Obstetrics and the Diseases of Women and Children, 65(3): 383-404.

Frizzelle, Mark. 1917. "The Elimination of Ignorant Midwifery: Either its Education, Licensure, or its Suppression.” New Charlotte Medical Journal, 76(3): 103-107.

Goldin, Claudia. 1990. Understanding the Gender Wage Gap: An Economic History of American Women. New York, NY: Oxford University Press.

Gittleman, Maury and Morris Kleiner. 2016. "Wage Effects of Unionization and Occupational Licensing Coverage in the United States.” Industrial and Labor Relations Review, 69(1): 142-172.

Guyer, Bernard Mary Anne Freedman, Donna M. Strobino, Edward J. Sondik. 2000. "Annual Summary of Vital Statistics: Trends in the Health of Americans During the $20^{\text {th }}$ Century." Pediatrics, 106 (6): 1307-1317.

Haines, Michael. 2001. “The Urban Mortality Transition in the United States, 1800-1940.” NBER Historical Paper No. 134.

Hamowy, Ronald. 1979. "The Early Development of Medical Licensing Laws in the United States, 1875-1900.” Journal of Libertarian Studies, 3(1):73-119.

Han, J.J., H.E. Yim, J.H. Lee, Y.K. Kim, G.Y. Jang, B.M. Choi, K.H. Yoo and Y.S. Hong. 2009. "Albumin versus Normal Saline for Dehydrated Term Infants with Metabolic Acidosis due to Acute Diarrhea." Journal of Perinatology, 29(6): 444-447. 
Hanson, Henry. 1931. "Protection of Motherhood." Florida Health Notes, 23(10): 149-150. Available at:

https://archive.org/stream/FloridaHealthNotes1931/1931 23\#page/n147/mode/2up/search/mid wifery.

Hardin, E.R. 1925. “The Midwife Problem.” Southern Medical Journal, 18(5): 347-350.

Henning, Wilbur Fisk and William Harvey Hyatt. 1921. Henning's General Laws of California as Amended and in Force at the Close of the Forty-Third Session of the Legislature, 1919: Including Initiative and Referendum Acts Adopted at the General Election of 1920, The Practice of Medicine Act of 1913, Act 2809, Amendment of April 11, 1917. San Francisco, CA: Bender-Moss Company.

Högberg, Ulf, Siabh Wallb and Göran Broströmc 1986. "The Impact of Early Medical Technology on Maternal Mortality in late 19th Century Sweden." International Journal of Gynecology and Obstetrics, 24(4): 251-261

Holmes, Rudolph. 1920. "Midwife Practice - An Anachronism." The Illinois Medical Journal, 37 (January): 27-31.

Howe, Chas. 1921. "The Relation of the Child Hygiene Division to the School and Home." Arizona Public Health News, 9(19): 3-5.

Huffman, Sandra and Cheryl Combest. 1990. "Role of Breast-Feeding in the Prevention and Treatment of Diarrhoea." Journal of Diarrhoeal Diseases Research, 8(3): 68-81.

Huntington, James Lincoln. 1913. “The Midwife in Massachusetts: Her Anomalous Position.” Boston Medical and Surgical Journal, 168(11): 418-421.

Illinois State Board of Health. 1879. First Annual Report of the State Board of Health of Illinois. Springfield IL: Weber, Magie \& Company, State Printer.

Jacobi, Abraham. 1912. "The Best Means of Combating Infant Mortality." Journal of the American Medical Association, 58(23): 1735-1744.

Jacobson, Paul H. 1956. "Hospital Care and the Vanishing Midwife." The Milbank Memorial Fund Quarterly, 34(3): 253-261.

Jayachandran, Seema, Adriana Lleras-Muney and Kimberly Smith. 2010. "Modern Medicine and the Twentieth Century Decline in Mortality: Evidence on the Impact of Sulfa Drugs." American Economic Journal: Applied Economics, 2(2): 118-46.

Jeidell, Helmina and Willa Fricke. 1912. "The Midwives of Anne Arundel County, Maryland." Bulletin of the Johns Hopkins Hospital, 23(259): 279-281.

Jewett, Charles and Harold Flagg Jewett. 1901. Essentials of Obstetrics. New York, NY: Lea Brothers \& Company. 
Johnstone, Robert William 1913. A Text-book of Midwifery for Students and Practitioners. New York, NY: The Macmillan Company.

Kitron, Uriel and Andrew Spielman. 1989. "Suppression of Transmission of Malaria through Source Reduction: Antianopheline Measures Applied in Israel, the United States, and Italy." Reviews of Infectious Diseases, 11(3): 391-406.

Kleiner, Morris. 2000. “Occupational Licensing.” Journal of Economic Perspectives, 14(4): 189-202.

Kleiner, Morris. 2015. Guild-Ridden Labor Markets. Kalamazoo, MI: W.E. Upjohn Institute for Employment Research.

Kleiner, Morris and Alan Krueger. 2010. "The Prevalence and Effects of Occupational Licensing." British Journal of Industrial Relations, 48(4): 676-687.

Kleiner, Morris and Alan Krueger. 2013. "Analyzing the Extent and Influence of Occupational Licensing on the Labor Market.” Journal of Labor Economics, 31(S1): S173 - S202.

Kleiner, Morris and Robert Kurdle. 2000. "Does Regulation Affect Economic Outcomes? The Case of Dentistry." Journal of Law and Economics, 43(2): 547-576.

Kleiner, Morris, Allison Marier, Kyoung Won Park and Coady Wing. 2014. "Relaxing Occupational Licensing Restrictions: Analyzing Wages and Prices from a Medical Service." NBER Working Paper No. 19906.

Kobrin, Frances. 1966. "The American Midwife Controversy: A Crisis of Professionalization.” Bulletin of the History of Medicine, 40(4): 350-363.

Koehler, Gottfried and C. St. Claire Drake. 1911. "The Prevention of Infant Mortality." Journal of the American Medical Association, 56(1): 20-26.

Kotelchuck, Milton. 2007. "Safe Mothers, Healthy Babies: Reproductive Health in the Twentieth Century." In John Ward and Christian Warren (eds.), Silent Victories: The History and Practice of Public Health in Twentieth Century America. New York, NY: Oxford University Press.

Knopf, Sigard. 1922. A History of the National Tuberculosis Association: The Anti-tuberculosis Movement in the United States. Philadelphia, PA: WM. F. Fell Co.

Larsen, Bradley. 2015. "Occupational Licensing and Quality: Distributional and Heterogeneous Effects in the Teaching Profession.” Working paper, Stanford University.

Leavitt, Judith. 1983. "'Science' Enters the Birthing Room: Obstetrics in America since the Eighteenth Century.” Journal of American History, 70(2): 281-304.

Leavitt, Judith. 1986. Brought to Bed: Child-Rearing in America, 1750-1950. New York, NY: Oxford University Press. 
Lebergott, Stanley. 1966. “Labor Force and Employment, 1800-1960.” In Dorothy S. Brady (ed.), Output, Employment, and Productivity in the United States after 1800. Cambridge, MA: NBER.

Levy, Julius. 1918. "The Maternal and Infant Mortality in Midwifery Practice in Newark, N.J." American Journal of Obstetrics and Diseases of Women and Children, 77(1): 41-53.

Levy, Julius. 1921. "Report of the Bureau of Child Hygiene." In the Fourth-Fourth Annual Report of the Department of Health of the State of New Jersey. Trenton, NJ: State of New Jersey.

Levy, Julius. 1923. "Maternal Mortality and Mortality in the First Month of Life in Relation to Attendant at Birth." American Journal of Public Health, 13(2): 88-95

Lewis, H. Gregg. 1986. Union Relative Wage Effects: A Survey. Chicago, IL: University of Chicago.

Linder, Forrest and Robert Grove. 1947. Vital Statistics Rates in the United States 1900-1940.

Washington, DC: United States Government Printing Office.

Loudon, Irvine. 1999. "The Measurement of Maternal Mortality." Journal of the History of Medicine, 54(April), 312-329.

Loudon, Irvine. 2000a. "Maternal Mortality in the Past and its Relevance to Developing Countries Today." American Journal of Clinical Nutrition, 72(1): 241s-246s.

Loudon, Irvine. 2000b. The Tragedy of Childbed Fever. New York, NY: Oxford University Press.

Mendenhall, Dorothy Reed. 1917. "Prenatal and Natal Conditions in Wisconsin." Wisconsin Medical Journal, 15(10): 353-369.

Miller Grant. 2008. "Women's Suffrage, Political Responsiveness, and Child Survival in American History.” Quarterly Journal of Economics, 123(3):1287-1327.

Mississippi Board of Health. 1921. "Supervision of Midwives." In the Report of the Board of Health of Mississippi, Volume 2. Jacksonville, Mississippi.

Missouri (state). 1909. The Revised Statutes of the State of Missouri, 1909, Volume 2, Article II, Midwifery, Sections 8320-8323, pp. 2609-2610. Jefferson City, MO: Hugh Stephens Printing Company.

Moehling, Carolyn and Melissa Thomasson. 2012. "The Political Economy of Saving Mothers and Babies: The Politics of State Participation in the Sheppard-Towner Program." Journal of Economic History, 72(1): 75-103.

Moehling, Carolyn and Melissa Thomasson. 2014. "Saving Babies: The Contribution of SheppardTowner to the Decline in Infant Mortality in the 1920s." Demography, 51(2): 367-386.

Molina, Natalia. 2006. Fit to be Citizens?: Public Health and Race in Los Angeles, 1879-1939. Berkeley, CA: University of California Press. 
Nathan, Lawrence and Kenneth Leveno. 1994. "Group A Streptococcal Puerperal Sepsis: Historical Review and 1990s Resurgence." Infectious Diseases in Obstetrics and Gynecology, 1(5): 252-255.

New York City Department of Health. 1921. Annual Report of the Board of Health of the Department of Health of the City of New York. "Supervision of Midwives." New York: M.B. Brown Printing and Binding Company, pp. 138-142.

New York Department of Health. 1909. "Regulations Governing the Practice of Midwifery in the City of New York." Annual Report of the Dept. of Health of the City of New York. New York: Martin B. Brown and Company, Printers and Stationers.

New York Bureau of Child Hygiene.1915. "Midwifery-Practice of-Schools for.” In the Municipal Ordinances, Rules, and Regulations Pertaining to Public Health 1915 (1917). Washington, DC: Government Printing Office.

New York Department of Health. 1915. "Notes from the State Department of Health: The Control of Midwives." New York State Journal of Medicine, 15(8): 323.

Nicholson, William. 1921. "An Anachronism of the Twentieth Century, the Midwife." Transactions of the College of Physicians of Philadelphia, Appendix: 495-522.

O’Connor, Patrick., 2015. “'Spitting Positively Forbidden': The Anti-Spitting Campaign, 1896-

1910.” Theses, Dissertations, Professional Papers. Paper 4449, University of Montana.

Olmstead, Alan and Paul Rhode. 2004a. "An Impossible Undertaking: The Eradication of Bovine Tuberculosis in the United States." Journal of Economic History, 64(3): 734-772.

Olmstead, Alan and Paul Rhode. 2004b. "The 'Tuberculous Cattle Trust': Disease Contagion in an Era of Regulatory Uncertainty.” Journal of Economic History, 64(4): 929-963.

Plecker, 1915. "The Midwife Problem in Virginia." Transactions of the Forty-Fifth Annual Session of the Medical Society of Virginia. Richmond, VA: The Richmond Press, Inc.

Pudup, Mary Beth. 1990. "Women's Work in the West Virginia Economy." West Virginia History, 49: 7-20.

Rausch, Christopher. 2008. "The Midwife and the Forceps: The Wild Terrain of Midwifery Law in the United States and Where North Dakota is Heading in the Birthing Debate." North Dakota Law Review, 84(1): 219-255.

Reaves, Jessica. 2010. "Use of Midwives Rises, Challenging the State to Respond" New York. Times, September 23. Available at: http://www.nytimes.com/2010/09/24/us/24cncmidwives.html.

Rini, Jen. 2015. "Delaware's Home Birth Debate Puts Mothers in the Middle.” USA Today, February 3. Available at:

http://www.usatoday.com/story/news/2015/02/03/home-birth-debate-delaware/22813849/. 
Robinson, Sharon. 1984 “A Historical Development of Midwifery in the Black Community: 16001940.” The Journal of Nurse Midwifery, 29 (4): 247-250.

Rooks, Judith Pence. 1997. Midwifery and Childbirth in America. Philadelphia, PA: Temple University Press.

Rude, Anna E. 1922. “The Sheppard-Towner Act in Relation to Public Health.” Journal of the American Medical Association, 79(12): 959-962.

Sandvick, Clinton. 2009. "Enforcing Medical Licensing in Illinois: 1877-1890." Yale Journal of Biology and Medicine, 82(2): 67-74.

Sass, Tim. 2015. "Licensure and Worker Quality: A Comparison of Alternative Routes to Teaching." Journal of Law and Economics, 58(1): 1-35.

Shapiro Carl. 1986. "Investment, Moral Hazard, and Occupational Licensing." Review of Economic Studies, 53(5): 843-862.

Shepard, Lawrence. 1978. "Licensing Restrictions and the Cost of Dental Care." Journal of Law and Economics, 2(1): 187-201.

Smith, Susan. 2005. Japanese American Midwives: Culture, Community, and Health Politics, 1880-1950.

Chicago, IL: University of Illinois Press.

Sobel, Jacob. 1918. "Instruction and Supervision of Expectant Mother in New York City." New York Medical Journal, 107(2): 49-55.

Stedman, Thomas L. 1920. “Obstetrics and the State.” Medical Record, 17(July): 104-105

Tarozzi, Alessandro Aprajit Mahajan, Brian Blackburn, Dan Kopf, Lakshmi Krishnan and Joanne Yoong. 2014. "Micro-loans, Insecticide-Treated Bednets, and Malaria: Evidence from a Randomized Controlled Trial in Orissa, India." American Economic Review, 104(7): 1909-1941.

Terry, Charles. 1917. "Save the Seventh Baby" The Delineator, 91(6): 19-20.

Texas (state). 1916. Vernon's Criminal Statutes of Texas, Volume 1: The Penal Code, Chapter 6, Unlawful Practice of Medicine, Art 754. Kansas City, MO: Vernon Law Book Company.

Texas Bureau of Child Hygiene (State Board of Health). 1925. "Report on Midwife Work." Available in Litoff, Judy B. (ed.), The American Midwife Debate: A Sourcebook on its Modern Origins. New York, NY: Greenwood Press.

Thomas, Duncan, Elizabeth Frankenberg, Jed Friedman, Jean-Pierre Habicht, Mohammed Hakimi, Nicholas Ingwersen, Jaswadi, Nathan Jones, Christopher McKelvey, Gretel Pelto, Bondan Sikoki, Teresa Seeman, James Smith, Cecep Sumantri, Wayan Suriastini and Siswanto Wilopo. 2006. "Causal Effect of Health on Labor Market Outcomes: Experimental Evidence." CCPR-070-06. Available at: http://escholarship.org/uc/item/0g28k77w. 
Thomasson, Melissa and Jaret Treber. 2008. "From Home to Hospital: The Evolution of Childbirth in the United States, 1928-1940." Explorations in Economic History, 45(1): 76-99.

Thompson, Joyce, Judith Fullerton and Angela Sawyer. 2011. "The International Confederation of Midwives: Global Standards for Midwifery Education (2010) with Companion Guidelines.” Midwifery, 27(4): 409-416.

Thornton, Robert and Edward Timmons. 2013. "Licensing One of the World's Oldest Professions: Massage.” Journal of Law and Economics, 56(2): 371-388

Timmons, Edward and Robert Thornton. 2008. "The Effects of Licensing on the Wages of Radiologic Technologists." Journal of Labor Research, 29(4): 333-346.

Tomkins, Andrew. 2001. "Nutrition and Maternal Morbidity and Mortality." British Journal of Nutrition, 85(S2): S93-S99.

UNFPA 2011. The State of the World's Midwifery 2011: Delivering Health, Saving Lives. Available at:

http://www.unfpa.org/sites/default/files/pub-pdf/en SOWMR Full.pdf.

U.S. Children's Bureau. 1931. The Promotion of the Welfare and Hygiene of Maternity and Infancy. Bureau Publication 203. Washington, DC: United States Government Printing Office.

van Blarcom, Carolyn Conant. 1913. The Midwife in England: Being a Study in England of the Working of the English Midwives Act of 1902. New York, NY: Committee for the Prevention of Blindness.

Washington (state). 1919. Pierce's Code, State of Washington, Cyclopedic Arrangement, Including Laws 1919, Act 1917 to Regulate \$3755. Seattle, WA: National Law Book Company.

Wertz, Richard and Dorothy Wertz. 1977. Lying-In: A History of Childbirth in America. New York, NY: The Free Press.

White, William. 1978. "The Impact of Occupational Licensure of Clinical Laboratory Personnel.” Journal of Human Resources, 13(1): 91-102.

WHO. 2005. "World Health Report: Make Every Mother and Child Count." Geneva, CH: WHO. Available at:

http://www.who.int/whr/2005/whr2005 en.pdfua=1.

WHO. 2014. “Trends in Maternal Mortality: 1990 to 2013.” Estimates by WHO, UNICEF, UNFPA, the World Bank and the United Nations Population Division. Geneva, CH: WHO. Available at:

http://apps.who.int/iris/bitstream/10665/112682/2/9789241507226 eng.pdf?ua=1.

Williams, Linsly. 1915. "The Position of the New York State Department of Health Relative to the Control of Midwives.” New York State Journal of Medicine, 15(8): 296-301. 
Williams, J. Whitridge. 1912. "Medical Education and the Midwife Problem in the United States." Journal of the American Medical Association, 58(January): 1-7.

Wisconsin (state). 1909. The Laws of Wisconsin: Joint Resolutions and Memorials Passed at the Biennial Session of the Legislature, 1909, Chapter 528. Madison, WI: Democratic Printing Company, State Printer.

Woodbury, Robert. 1924. "The Trend of Maternal-Mortality Rates in the United States Death Registration Area, 1900-1921." American Journal of Public Health, 14(9): 738-743.

Wolf, Jacqueline. 2003. "Low Breastfeeding Rates and Public Health in the United States." American Journal of Public Health, 93(12): 2000-2010. 
Figure 1. Passage of Midwife Licensing Requirements

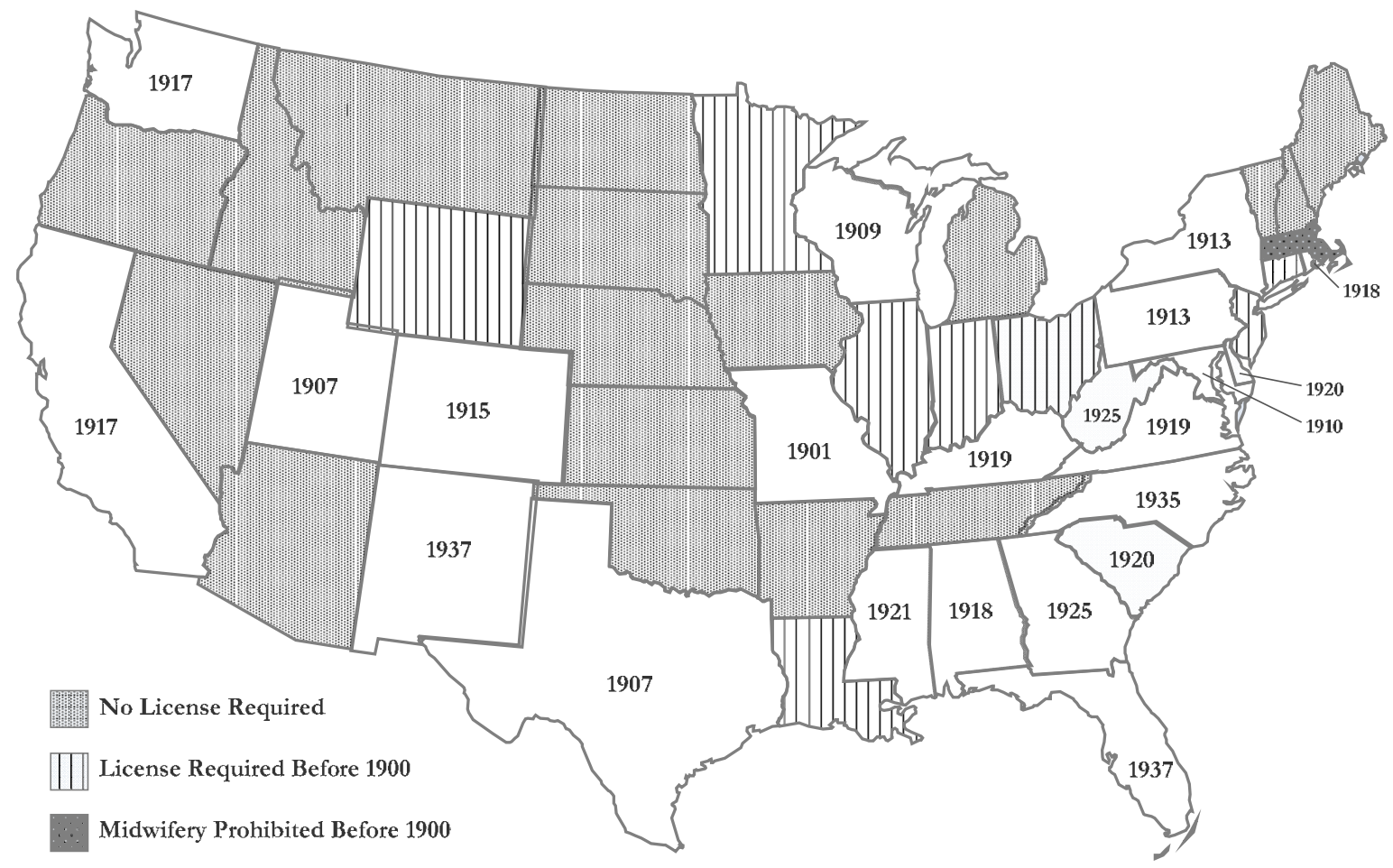

Notes: Years are for when midwives were first required to be licensed. Sources are provided in Appendix Table 1. The District of Columbia required midwives to be licensed in 1896 . An ordinance adopted in 1907 required midwives practicing in New York City to be licensed. 


\section{Figure 2. Pre- and Post-Licensing Trends in Maternal Mortality}

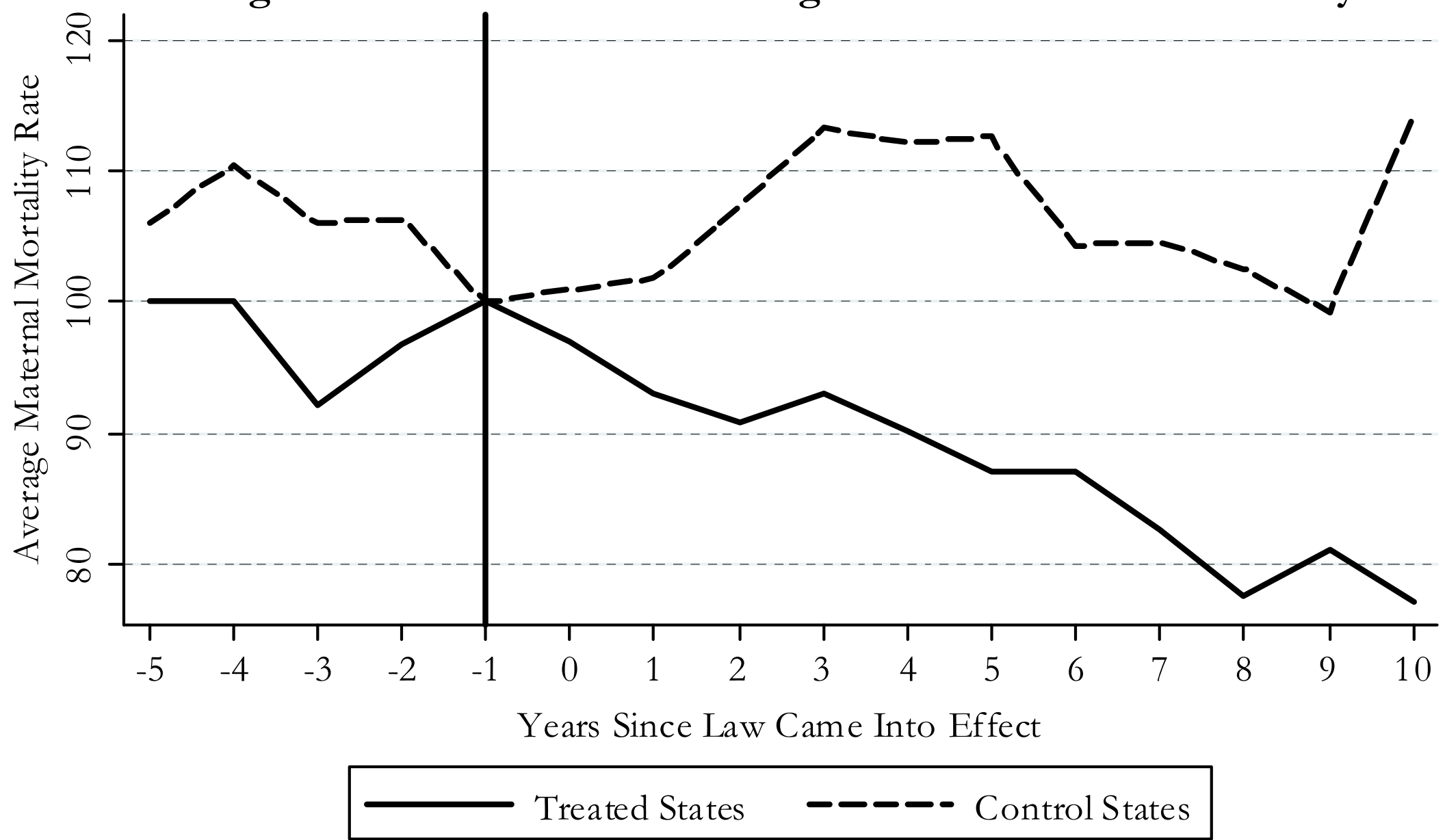

Based on annual data from Mortality Statistics, published by the U.S. Census Bureau. On the horizontal axis, 0 represents the year in which midwifery became a licensed profession. It was randomly assigned to states with un regulated midwifery during the period under study. Maternal mortality rates are expressed relative to year -1 . 
Table 1. Descriptive Statistics for State-Level Maternal Mortality Analysis, 1900-1940

\begin{tabular}{|c|c|c|c|c|}
\hline & Full sample & $\begin{array}{c}\text { Midwifery License } \\
\text { Required }=1\end{array}$ & $\begin{array}{c}\text { Midwifery License } \\
\text { Required }=0\end{array}$ & Description \\
\hline \multirow[t]{2}{*}{ Maternal Mortality } & $27.9(11.1)$ & $26.7(10.1)$ & $29.3(12.0)$ & Maternal mortality per 100,000 female population \\
\hline & $\mathrm{N}=1,296$ & $\mathrm{~N}=711$ & $\mathrm{~N}=585$ & \\
\hline$\%$ Pop $<18$ & $.351(.045)$ & $.352(.046)$ & $.350(.043)$ & Percent of population less that was than 18 years of age \\
\hline$\%$ Pop 18-65 & $.598(.037)$ & $.600(.038)$ & $.597(.036)$ & Percent of population that was $18-65$ years of age \\
\hline$\%$ White & $.899(.134)$ & $.882(.141)$ & $.919(.121)$ & Percent of population that was white \\
\hline$\%$ Black & $.079(.128)$ & $.101(.142)$ & $.052(.102)$ & Percent of population that was black \\
\hline$\%$ Urban & $.482(.183)$ & $.523(.186)$ & $.431(.166)$ & Percent of population that lived in an urban area \\
\hline$\%$ Female & $.489(.018)$ & $.493(.014)$ & $.485(.022)$ & Percent of population that was female \\
\hline$\%$ Foreign & $116(.091)$ & $107(.090)$ & $.126(.091)$ & Percent of population that was foreign born \\
\hline Physicians per Capita & $131.8(45.5)$ & $129.4(41.3)$ & $134.6(49.9)$ & Physicians per 100,000 population \\
\hline Physician Diploma & $.962(.191)$ & $.982(.134)$ & $.938(.241)$ & $=1$ if state required physicians to have a diploma \\
\hline Physician Education & $.952(.214)$ & $.989(.106)$ & $.908(.290)$ & $=1$ if state medical boards could set preliminary education requirements \\
\hline Dept. of Child Hygiene & $.726(.446)$ & $.820(.384)$ & $.612(.488)$ & $=1$ if state had a division of child hygiene \\
\hline Suffrage & $.767(.423)$ & $.823(.382)$ & $.699(.459)$ & $=1$ if women were allowed to vote \\
\hline ST Act & $4.15(10.2)$ & $5.26(12.2)$ & $2.80(6.84)$ & For 1930, sum of Sheppard-Towner spending for 1922-1929 $(\$ 1,000)$ \\
\hline Typhoid & $8.87(9.30)$ & $7.75(8.29)$ & $10.2(10.2)$ & Typhoid mortality per 100,000 population \\
\hline Non-pulmonary TB & $11.1(7.04)$ & $10.1(5.93)$ & $12.4(8.01)$ & Non-pulmonary tuberculosis mortality per 100,000 population \\
\hline
\end{tabular}

Notes: Unweighted means with standard deviations in parentheses. 
Table 2. Maternal Mortality and Midwifery Laws: State-Level Analysis, 1900-1940

\begin{tabular}{|c|c|c|c|c|c|}
\hline & (1) & $(2)$ & (3) & (4) & $(5)$ \\
\hline Year Prior to Midwifery License Required & $\ldots$ & $\ldots$ & $\ldots$ & $\ldots$ & $\begin{array}{l}-.006 \\
(.019)\end{array}$ \\
\hline Midwifery License Required & $\begin{array}{c}-.062^{* *} \\
(.025)\end{array}$ & $\begin{array}{c}-.064^{* *} \\
(.026)\end{array}$ & $\begin{array}{c}-.062^{* *} \\
(.027)\end{array}$ & $\begin{array}{c}-.062^{* *} \\
(.024)\end{array}$ & $\begin{array}{c}-.063^{* *} \\
(.024)\end{array}$ \\
\hline Mean & 27.9 & 27.9 & 27.9 & 27.9 & 27.9 \\
\hline $\mathrm{N}$ & 1,296 & 1,296 & 1,296 & 1,296 & 1,296 \\
\hline $\mathrm{R}^{2}$ & .953 & .955 & .956 & .965 & .965 \\
\hline Policy controls & no & yes & yes & yes & yes \\
\hline Typhoid and non-pulmonary TB & no & no & yes & yes & yes \\
\hline State-specific linear trends & no & no & no & yes & yes \\
\hline
\end{tabular}

*Statistically significant at $10 \%$ level; ** at $5 \%$ level; *** at $1 \%$ level.

Notes: Based on annual data from Mortality Statistics, published by the U.S. Census Bureau. Each column represents the results from a separate OLS regression. The dependent variable is equal to the natural $\log$ of the maternal mortality rate per 100,000 females in state $s$ and year $t$. Controls include $\%$ of population less than 18 years of age, $\% 18-65$ years of age, $\%$ white, $\%$ black, $\%$ living in an urban area, $\%$ female, $\%$ foreign born, physicians per capita, state fixed effects and year fixed effects. Regressions are weighted by female population. Standard errors, corrected for clustering at the state level, are in parentheses. 
Table 3. Falsification Outcomes and Midwifery Laws: State-Level Analysis, 1900-1940

\begin{tabular}{|c|c|c|c|c|c|c|c|c|}
\hline \multirow[b]{2}{*}{ Midwifery License Required } & \multicolumn{2}{|c|}{ Pulmonary Tuberculosis } & \multicolumn{2}{|c|}{ Malaria } & \multicolumn{2}{|c|}{ Influenza } & \multicolumn{2}{|c|}{ Diabetes } \\
\hline & $\begin{array}{c}.036 \\
(.023)\end{array}$ & $\begin{array}{c}.018 \\
(.017)\end{array}$ & $\begin{array}{c}.042 \\
(.033) \\
{[.391]}\end{array}$ & $\begin{array}{c}.039 \\
(.042) \\
{[.357]}\end{array}$ & $\begin{array}{c}.019 \\
(.059)\end{array}$ & $\begin{array}{c}.077 \\
(.051)\end{array}$ & $\begin{array}{l}.055^{*} \\
(.031)\end{array}$ & $\begin{array}{c}.008 \\
(.017)\end{array}$ \\
\hline Mean & 81.6 & 81.6 & 3.05 & 3.05 & 37.2 & 37.2 & 17.8 & 17.8 \\
\hline $\mathrm{N}$ & 1,296 & 1,296 & 1,296 & 1,296 & 1,296 & 1,296 & 1,296 & 1,296 \\
\hline Typhoid and non-pulmonary TB & no & yes & no & yes & no & yes & no & yes \\
\hline State-specific linear trends & no & yes & no & yes & no & yes & no & yes \\
\hline
\end{tabular}

*Statistically significant at $10 \%$ level; ** at $5 \%$ level; *** at $1 \%$ level.

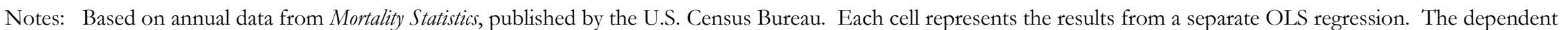
variable is equal to the natural $\log$ (or, in the case of malaria, the quartic root) of the specified mortality rate per 100,000 population in state $s$ and year $t$. Controls include $\%$ of population less than 18 years of age, $\% 18-65$ years of age, $\%$ white, $\%$ black, $\%$ living in an urban area, $\%$ female, $\%$ foreign born physician, physicians per capita, physician educational requirements, a department of child hygiene indicator, a women's suffrage indicator, Sheppard-Towner spending, state fixed effects and year fixed effects. Regressions are weighted by state population. Standard errors, corrected for clustering at the state level, are in parentheses and marginal effects are in brackets. 
Table 4. Heterogeneous Effects and Midwifery Laws: State-Level Analysis, 1900-1940

\begin{tabular}{|c|c|c|c|c|c|}
\hline & $\begin{array}{l}\text { Maternal } \\
\text { Mortality }\end{array}$ & $\begin{array}{c}\text { Urban } \\
\text { Maternal } \\
\text { Mortality }\end{array}$ & $\begin{array}{c}\text { Rural } \\
\text { Maternal } \\
\text { Mortality }\end{array}$ & $\begin{array}{c}\text { Maternal } \\
\text { Mortality due to } \\
\text { Puerperal Fever }\end{array}$ & $\begin{array}{c}\text { Maternal } \\
\text { Mortality due to } \\
\text { Other Causes }\end{array}$ \\
\hline Midwifery License Required & $\begin{array}{c}-.036^{* * *} \\
(.013)\end{array}$ & $\begin{array}{c}-.109 * * * \\
(.040)\end{array}$ & $\begin{array}{l}-.027 \\
(.026)\end{array}$ & $\begin{array}{l}1.072^{*} \\
(.037)\end{array}$ & $\begin{array}{c}-.055^{* *} \\
(.023)\end{array}$ \\
\hline $\begin{array}{l}\text { Midwifery License Required * } \\
\text { Exam Sufficient }\end{array}$ & $\begin{array}{l}-.026 \\
(.034)\end{array}$ & $\ldots$ & $\ldots$ & $\ldots$ & $\ldots$ \\
\hline $\begin{array}{l}\text { Midwifery License Required * } \\
\text { Graduation Necessary }\end{array}$ & $\begin{array}{l}-.052 \\
(.054)\end{array}$ & $\ldots$ & $\ldots$ & $\ldots$ & $\ldots$ \\
\hline $\begin{array}{l}\text { Mean } \\
\mathrm{N}\end{array}$ & $\begin{array}{c}27.9 \\
1,296\end{array}$ & $\begin{array}{c}17.7 \\
1,296\end{array}$ & $\begin{array}{c}11.6 \\
1,296\end{array}$ & $\begin{array}{c}10.5 \\
1,296\end{array}$ & $\begin{array}{c}17.5 \\
1,296\end{array}$ \\
\hline
\end{tabular}

*Statistically significant at $10 \%$ level; ** at $5 \%$ level; *** at $1 \%$ level.

Notes: Based on annual data from Mortality Statistics, published by the U.S. Census Bureau. Each column represents the results from a separate OLS regression. The dependent variable is equal to the natural $\log$ of the specified mortality rate per 100,000 females from the relevant population in state $s$ and year $t$. Controls include \% of population less than 18 years of age, \% 18-65 years of age, $\%$ white, $\%$ black, $\%$ living in an urban area, $\%$ female, $\%$ foreign born, physicians per capita, physician educational requirements, a department of child hygiene indicator, a women's suffrage indicator, Sheppard-Towner spending, the typhoid mortality rate, the nonpulmonary tuberculosis mortality rate, state fixed effects, year fixed effects and state-specific linear time trends. Regressions are weighted by the relevant female population. Standard errors, corrected for clustering at the state level, are in parentheses. 
Table 5. Maternal Mortality and Midwifery Laws: Municipal-Level Analysis, 1900-1917

\begin{tabular}{lcccc} 
& $(1)$ & $(2)$ & $(3)$ & $(4)$ \\
\hline Midwifery License Required & $-.093^{* * *}$ & $-.082^{* * *}$ & -.029 & -.020 \\
& $(.028)$ & $(.025)$ & $(.023)$ & $(.019)$ \\
& {$[-2.98]$} & {$[-2.63]$} & {$[-.925]$} & {$[-.649]$} \\
Mean & & & & 16.0 \\
$\mathrm{~N}$ & 16.0 & 16.0 & 6,365 & 6,365 \\
$\mathrm{R}^{2}$ & 6,365 & 6,365 & .350 & .434 \\
& .321 & .335 & yes & yes \\
Typhoid and non-pulmonary TB & & & yes & no \\
State-specific linear trends & no & yes & no & yes \\
Municipality-specific linear trends & no & no & no &
\end{tabular}

*Statistically significant at $10 \%$ level; ** at $5 \%$ level; *** at $1 \%$ level.

Notes: Based on annual data from Mortality Statistics, published by the U.S. Census Bureau. Each column represents the results from a separate OLS regression. The dependent variable is equal to the quartic root of the maternal mortality rate per 100,000 population in municipality $m$ and year $t$. Controls include physician educational requirements, a department of health indicator, a department of child hygiene indicator, a women's suffrage indicator, municipality fixed effects and year fixed effects. Regressions are weighted by municipality population. Standard errors, corrected for clustering at the state level, are in parentheses and marginal effects are in brackets. 
Table 6. Infant Mortality and Midwifery Laws

\begin{tabular}{|c|c|c|c|c|c|c|c|c|c|c|}
\hline & \multicolumn{3}{|c|}{ State-level analysis, 1900-1940 } & & \multicolumn{6}{|c|}{ Municipal-level analysis, 1900-1917 } \\
\hline & $\begin{array}{c}\text { Infant } \\
\text { Mortality }\end{array}$ & $\begin{array}{c}\text { White } \\
\text { Infant } \\
\text { Mortality }\end{array}$ & $\begin{array}{c}\text { Nonwhite } \\
\text { Infant } \\
\text { Mortality }\end{array}$ & & $\begin{array}{c}\text { Infant } \\
\text { Mortality }\end{array}$ & $\begin{array}{c}\text { Infant } \\
\text { Mortality }\end{array}$ & $\begin{array}{c}\text { Diarrbea } \\
\text { Under Age } 2\end{array}$ & $\begin{array}{c}\text { Diarrhea } \\
\text { Under Age } 2\end{array}$ & $\begin{array}{l}\text { Diarrhea } \\
\text { Ages 2+ }\end{array}$ & $\begin{array}{l}\text { Diarrhea } \\
\text { Ages 2+ }\end{array}$ \\
\hline $\begin{array}{l}\text { Midwifery } \\
\text { License Required }\end{array}$ & $\begin{array}{c}.005 \\
(.016)\end{array}$ & $\begin{array}{c}.002 \\
(.024)\end{array}$ & $\begin{array}{c}-.049 * \\
(.027) \\
{[-12.4]}\end{array}$ & $\begin{array}{l}\text { Midwifery } \\
\text { License Required }\end{array}$ & $\begin{array}{l}-.035 \\
(.044)\end{array}$ & $\begin{array}{c}.007 \\
(.014)\end{array}$ & $\begin{array}{c}-.080^{*} \\
(.047) \\
{[-9.25]}\end{array}$ & $\begin{array}{l}-.024^{*} \\
(.014) \\
{[-2.83]}\end{array}$ & $\begin{array}{l}-.045 \\
(.030) \\
{[-1.62]}\end{array}$ & $\begin{array}{c}-.003 \\
(.016) \\
{[-.119]}\end{array}$ \\
\hline $\begin{array}{l}\text { Mean } \\
\mathrm{N} \\
\mathrm{R}^{2}\end{array}$ & $\begin{array}{c}164.3 \\
1,296 \\
.990\end{array}$ & $\begin{array}{c}139.4 \\
1,114 \\
.989\end{array}$ & $\begin{array}{c}248.9 \\
1,114 \\
.940\end{array}$ & $\begin{array}{l}\text { Mean } \\
\mathrm{N} \\
\mathrm{R}^{2}\end{array}$ & $\begin{array}{c}306.2 \\
6,365 \\
.818\end{array}$ & $\begin{array}{c}306.2 \\
6,365 \\
.854\end{array}$ & $\begin{array}{c}89.2 \\
6,365 \\
.814\end{array}$ & $\begin{array}{c}89.2 \\
6,365 \\
.851\end{array}$ & $\begin{array}{c}18.7 \\
3,747 \\
.571\end{array}$ & $\begin{array}{c}18.7 \\
3,747 \\
.636\end{array}$ \\
\hline & & & & $\begin{array}{l}\text { State-specific linear } \\
\text { trends } \\
\text { Municipality- } \\
\text { specific } \\
\text { linear trends }\end{array}$ & $\begin{array}{l}\text { yes } \\
\text { no }\end{array}$ & $\begin{array}{l}\text { no } \\
\text { yes }\end{array}$ & $\begin{array}{l}\text { yes } \\
\text { no }\end{array}$ & $\begin{array}{l}\text { no } \\
\text { yes }\end{array}$ & $\begin{array}{l}\text { yes } \\
\text { no }\end{array}$ & $\begin{array}{l}\text { no } \\
\text { yes }\end{array}$ \\
\hline
\end{tabular}

*Statistically significant at $10 \%$ level; $* *$ at $5 \%$ level; *** at $1 \%$ level.

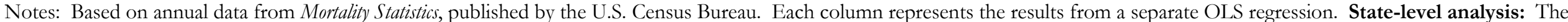

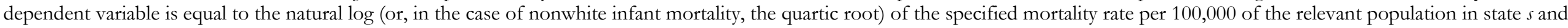

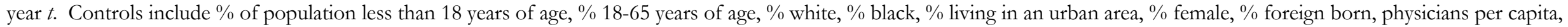

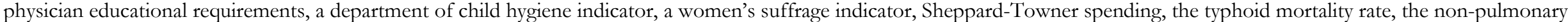

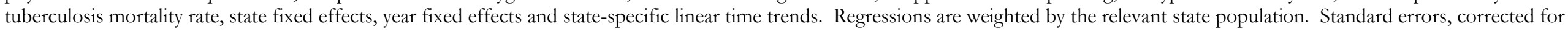

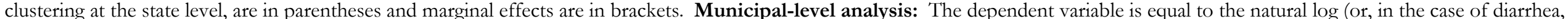

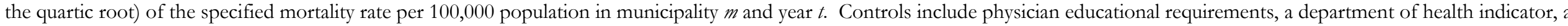

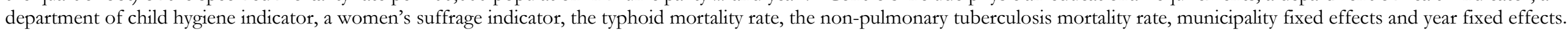
Regressions are weighted by municipality population. Standard errors, corrected for clustering at the state level, are in parentheses and marginal effects are in brackets. 


\section{Table 7. Licensing and the Supply of Midwives: Evidence from Census Years, 1870-1930}

\begin{tabular}{|c|c|c|c|c|c|c|}
\hline \multirow{4}{*}{ Midwifery License Required } & \multicolumn{2}{|c|}{ Total Midwives } & \multicolumn{2}{|c|}{ Black Midwives } & \multicolumn{2}{|c|}{ Foreign-Born Midwives } \\
\hline & $.569 * * *$ & $.677 * * *$ & .526 & .869 & .453 & .319 \\
\hline & $(.206)$ & $(.243)$ & $(.506)$ & $(.773)$ & $(.340)$ & $(.401)$ \\
\hline & {$[23.4]$} & {$[27.8]$} & [19.7] & {$[32.6]$} & {$[45.0]$} & {$[31.7]$} \\
\hline Mean & 22.3 & 22.3 & 19.7 & 19.7 & 72.4 & 72.4 \\
\hline $\mathrm{N}$ & 286 & 286 & 258 & 258 & 286 & 286 \\
\hline $\mathrm{R}^{2}$ & .605 & .721 & .564 & .647 & .644 & .728 \\
\hline State-specific linear trends & no & yes & no & yes & no & yes \\
\hline
\end{tabular}

*Statistically significant at $10 \%$ level; ** at $5 \%$ level; *** at $1 \%$ level.

Notes: Based on Decennial U.S. Census data at the state level. Each column represents the results from a separate OLS regression. The dependent variable is equal to the quartic root of the specified midwife rate per 100,000 females ages 15-45 from the relevant population in state $s$ and year $t$. Controls include $\%$ of population less than 18 years of age, $\% 18-65$ years of age, $\%$ white, $\%$ black, $\%$ living in an urban area, $\%$ female, $\%$ foreign born, physician educational requirements, a department of health indicator, a department of child hygiene indicator, a women's suffrage indicator, Sheppard-Towner spending, state fixed effects and year fixed effects. Regressions are weighted by the relevant female population, ages 15-45. Standard errors, corrected for clustering at the state level, are in parentheses and marginal effects are in brackets. 


\section{Appendix Table 1. State Midwifery Laws, 1870-1940}

\begin{tabular}{|c|c|c|c|}
\hline State & $\begin{array}{l}\text { Licensing } \\
\text { Requirement }\end{array}$ & $\begin{array}{l}\text { Year of } \\
\text { Passage }\end{array}$ & Description \\
\hline Alabama & Yes & 1918 & $\begin{array}{l}\text { Midwives were required to pass an examination and register with the } \\
\text { Alabama State Board of Health. According to Tovino (2004, p. 72), } \\
\text { "Although thousands of women practiced as lay midwives in Alabama, } \\
\text { only a few completed the required training." In response to the passage } \\
\text { of the law, the Tuskegee Institute developed a four-week course "of } \\
\text { intensive training in midwifery" (Kennedy 1921). }\end{array}$ \\
\hline Arizona & $\mathrm{No}$ & & $\begin{array}{l}\text { A } 1903 \text { law stipulated that the practice of midwifery be unrestricted } \\
\text { (van Blarcom 1913). }\end{array}$ \\
\hline Arkansas & No & & $\begin{array}{l}\text { A } 1904 \text { law stipulated that the practice of midwifery be unrestricted } \\
\text { (van Blarcom 1913). }\end{array}$ \\
\hline California & Yes & 1917 & $\begin{array}{l}\text { The law came into effect on July } 27,1917 \text {. It required that midwives } \\
\text { receive instruction in anatomy, hygiene and sanitation, obstetrics and } \\
\text { physiology from a legally chartered school approved by the Board of } \\
\text { Medical Examiners. Applicants also had to pass an examination in } \\
\text { these subjects. Persons practicing midwifery without a license were } \\
\text { subject to a fine of not more than } \$ 600 \text { and/or imprisonment for up to } \\
180 \text { days. The full text of the law is available in Henning and Hyatt } \\
(1921) \text {. }\end{array}$ \\
\hline Colorado & Yes & 1915 & $\begin{array}{l}\text { The law required that applicants be examined by the State Board of } \\
\text { Medical Examiners. Persons practicing midwifery without a license } \\
\text { were subject to a fine of not more than } \$ 300 \text { or imprisonment for up } \\
\text { to } 30 \text { days. See Colorado (1915) for the full text of the law. Also see } \\
\text { Stone (1918). }\end{array}$ \\
\hline Connecticut & Yes & 1893 & $\begin{array}{l}\text { The law came into effect in October } 1893 \text {. Applicants had to pass an } \\
\text { exam administered by a committee appointed by the State Board of } \\
\text { Health. Persons practicing midwifery without a license were subject to } \\
\text { a fine of not more than } \$ 300 \text { or imprisonment for up to } 90 \text { days. See } \\
\text { Connecticut (1893) for the full text of the law. }\end{array}$ \\
\hline Delaware & Yes & 1920 & $\begin{array}{l}\text { License to be issued by the State Board of Health upon a signed } \\
\text { statement from a licensed physician that the applicant is qualified. See } \\
\text { the National Committee for the Prevention of Blindness (1920) for } \\
\text { more details. }\end{array}$ \\
\hline Florida & Yes & 1931 & $\begin{array}{l}\text { The law required that applicants be at least } 21 \text { years of age, sponsored } \\
\text { by two practicing physicians, be able to read "the Manual for Midwives } \\
\text { intelligently" and show evidence "of habits of cleanliness." Applicants } \\
\text { were required to have attended } 15 \text { deliveries under the supervision of a } \\
\text { licensed physician or to have graduated from a school for midwives } \\
\text { recognized by the State Health Officer. See Hanson (1931) for the full } \\
\text { text of the law. }\end{array}$ \\
\hline Georgia & Yes & 1925 & $\begin{array}{l}\text { Midwives were required to receive basic instruction from public health } \\
\text { nurses in order to be certified. Beginning in 1956, applicants had to be }\end{array}$ \\
\hline
\end{tabular}


of "good character and sound mind." Under the new requirements, applicants who were not previously certified had to complete a course of instruction approved by the Georgia Department of Public Health and were required to pass an examination. Previously certified midwives were required to receive "periodic instruction made available to them each year in order to maintain eligibility for certification." See Georgia Department of Public Health (1928), Cadwallader (1957), Georgia (1957), Pennell and Stewert (1968) and Warsh (2010, pp. 108109) for details.

\begin{tabular}{|c|c|c|c|}
\hline Idaho & $\mathrm{No}$ & & $\begin{array}{l}\text { A } 1908 \text { law stipulated that the practice of midwifery be unrestricted } \\
\text { (van Blarcom 1913). }\end{array}$ \\
\hline Illinois & Yes & 1877 & $\begin{array}{l}\text { The law came into effect on July 1, } 1877 \text {. It created the State Board of } \\
\text { Health, which was empowered to examine midwives (and physicians) } \\
\text { who had not graduated from a medical institution "in good standing." } \\
\text { Persons practicing midwifery without a license were subject to a fine of } \\
\text { not more than } \$ 500 \text { and/or imprisonment for up to } 365 \text { days. See } \\
\text { Illinois State Board of Health (1884), Egan (1910) and Sandvick (2009) } \\
\text { for more details. }\end{array}$ \\
\hline Indiana & Yes & 1897 & $\begin{array}{l}\text { The law came into effect on April 14,1897. It required applicants to } \\
\text { have graduated from a recognized school of midwifery or pass an } \\
\text { examination given by the Board of Medical Registration and } \\
\text { Examination. Persons practicing midwifery without a license were } \\
\text { subject to a fine of not less than } \$ 25 \text { and not more than } \$ 500 \text { (Egan } \\
\text { 1910; van Blarcom 1913; Burns } 1914 \text {, pp. 142-144; Pennell and Stewart } \\
\text { 1968). }\end{array}$ \\
\hline Iowa & No & & $\begin{array}{l}\text { The practice of midwifery was unregulated until 1978, when it was } \\
\text { prohibited AG's opinion (Egan 1910; Pennell and Stewart 1968; Butter } \\
\text { and Kay 1988). }\end{array}$ \\
\hline Kansas & $\mathrm{No}$ & & $\begin{array}{l}\text { Under a } 1911 \text { law, midwives were required to register with the local } \\
\text { registrar of vital statistics (van Blarcom 1913). }\end{array}$ \\
\hline Kentucky & Yes & 1919 & $\begin{array}{l}\text { Established in 1919, the Bureau of Child Hygiene was tasked with } \\
\text { instructing, examining and licensing midwives "through county health } \\
\text { officers." See Kentucky (1922) for the full text of the law. }\end{array}$ \\
\hline Louisiana & Yes & 1894 & $\begin{array}{l}\text { The law required examination by the Board of Medical Examiners, but } \\
\text { exempted the "so-called midwife of the rural districts and plantation } \\
\text { practice, who, in the sense of this act, are not considered as practicing } \\
\text { midwifery as a profession." Persons practicing midwifery without a } \\
\text { license were subject to a fine of up to } \$ 100 \text { (Louisiana 1904; Duffy } \\
\text { 1962, p. 409; Pennell and Stewart 1968). }\end{array}$ \\
\hline Maine & $\mathrm{No}$ & & $\begin{array}{l}\text { A } 1903 \text { law stipulated that the practice of midwifery be unrestricted } \\
\text { (van Blarcom 1913). }\end{array}$ \\
\hline Maryland & Yes & 1910 & $\begin{array}{l}\text { The law came into effect on July 1, 1910. It required examination by } \\
\text { the State Board of Health. Applicants were also required to provide a } \\
\text { "certificate from a legal practitioner of medicine...that he or she has } \\
\text { attended at least } 5 \text { cases of childbirth" and had to provide certificates } \\
\text { from three "reputable citizens" attesting that the applicant was of good } \\
\text { moral character. See Maryland (1914) for the full text of the law. }\end{array}$ \\
\hline
\end{tabular}




\begin{tabular}{|c|c|c|c|}
\hline Massachusetts & No & & $\begin{array}{l}\text { The practice of midwifery was prohibited by the Medical Practice Act } \\
\text { of } 1894 \text { (Declercq 1994). }\end{array}$ \\
\hline Michigan & No & & $\begin{array}{l}\text { The practice of midwifery was (and remains) unregulated (Egan 1910; } \\
\text { Pennell and Stewart 1968; Butter and Kay 1988; Gray 2015). }\end{array}$ \\
\hline Minnesota & Yes & 1891 & $\begin{array}{l}\text { The law came into effect on April 20,1891. It required applicants to } \\
\text { have graduated from a recognized school of midwifery or pass an } \\
\text { examination administered by the Board of Medical Examiners. } \\
\text { Practicing midwifery without a license was subject to a fine of up to } \\
\$ 50 \text { or imprisonment of up to } 30 \text { days. See Minnesota (1891) for the } \\
\text { full text of the law. Also see Egan (1910). }\end{array}$ \\
\hline Mississippi & Yes & 1921 & $\begin{array}{l}\text { Beginning in 1921, the Bureau of Child Welfare provided instruction to } \\
\text { midwives and required them to be certified. Applicants were judged } \\
\text { based on character, cleanliness, intelligence and "reputation for calling } \\
\text { a doctor in difficult or abnormal cases." See Mississippi Board of } \\
\text { Health (1921) for more details. }\end{array}$ \\
\hline Missouri & Yes & 1901 & $\begin{array}{l}\text { Applicants had to pass an examination administered by the State Board } \\
\text { of Health. Women who did not practice midwifery as a profession and } \\
\text { did not charge for their services were not required to obtain a license. } \\
\text { Persons practicing midwifery as a profession without a license were } \\
\text { subject to a fine of not more than } \$ 50 \text { or imprisonment for up to two } \\
\text { months. See Missouri (1909) for the full text of the law. Also see Perry } \\
\text { (1983). }\end{array}$ \\
\hline Montana & $\mathrm{No}$ & & $\begin{array}{l}\text { The practice of midwifery was unregulated until 1978, when it was } \\
\text { prohibited AG's opinion (Egan 1910; Pennell and Stewart 1968; Butter } \\
\text { and Kay 1988). }\end{array}$ \\
\hline Nebraska & No & & $\begin{array}{l}\text { The practice of midwifery was unregulated (Egan 1910; van Blarcom } \\
\text { 1913; Pennell and Stewart 1968; Butter and Kay 1988). }\end{array}$ \\
\hline Nevada & No & & $\begin{array}{l}\text { The practice of midwifery was unregulated (Egan 1910; van Blarcom } \\
\text { 1913; Pennell and Stewart 1968; Butter and Kay 1988). }\end{array}$ \\
\hline $\begin{array}{c}\text { New } \\
\text { Hampshire }\end{array}$ & No & & $\begin{array}{l}\text { The practice of midwifery was unregulated (Egan 1910; van Blarcom } \\
\text { 1913; Pennell and Stewart 1968; Butter and Kay 1988). }\end{array}$ \\
\hline New Jersey & Yes & 1892 & $\begin{array}{l}\text { Under the law, applicants were required to have } 6 \text { months of training } \\
\text { from a legally incorporated school of midwifery and pass an } \\
\text { examination given by the Board of Medical Examiners. Practicing } \\
\text { midwifery without a license was punishable by a fine of not more than } \\
\$ 50 \text { and/or imprisonment for up to } 30 \text { days (New Jersey State Board of } \\
\text { Medical Examiners 1902). In 1910, the law was amended to require } \\
\text { two years of training (van Blarcom 1913; Levy 1921). }\end{array}$ \\
\hline New Mexico & Yes & 1937 & $\begin{array}{l}\text { A } 1901 \text { law stipulated that the practice of midwifery be unrestricted } \\
\text { (van Blarcom 1913). The } 1937 \text { law provided for licensure by } \\
\text { examination and set penalties for practicing midwifery without a license } \\
\text { (Pennell and Stewart 1968). }\end{array}$ \\
\hline New York & Yes & 1913 & $\begin{array}{l}\text { Applicants had to be at least } 21 \text { years of age, be able to read and write } \\
\text { and be of "good moral character." These requirements came into } \\
\text { effect on November 16, } 1914 \text { except in New York City and Rochester } \\
\text { (New York Department of Health 1915; Williams 1915). As of January } \\
\text { 1, 1915, applicants were required to show evidence of "habits of }\end{array}$ \\
\hline
\end{tabular}


cleanliness" and to have graduated from a recognized midwifery program or provide a statement from a licensed physician attesting that the applicant had attended and received instruction in at least 15 deliveries (Williams 1915).

\begin{tabular}{llll}
\hline North Carolina & Yes & $1935 \quad$ The practice of midwifery was unregulated until a 1908 law required
\end{tabular}
midwives to wash hands before touching a patient and banned women who were addicted to drugs or alcohol from the practice of midwifery (van Blarcom 1913). In 1917, midwives were required to register with the Board of Health (North Carolina 1920). In April of 1935, midwives were required to obtain a permit from the Board of Health, "under rules and regulations which it shall adopt with respect thereto..." Practicing midwifery without a permit was punishable by a fine of not more than $\$ 50$ or imprisonment for up to 30 days. See North Carolina (1935) for the full text of the law.

\begin{tabular}{|c|c|c|c|}
\hline North Dakota & No & & $\begin{array}{l}\text { The practice of midwifery was unregulated (Egan 1910; van Blarcom } \\
\text { 1913; Pennell and Stewart 1968; Butter and Kay 1988). }\end{array}$ \\
\hline Ohio & Yes & 1896 & $\begin{array}{l}\text { Applicants were required to pass an examination administered by the } \\
\text { State Board of Medical Registration and Examination. Practicing } \\
\text { midwifery without a license was punishable by a fine of not less than } \\
\$ 25 \text { and not more than } \$ 100 \text {. See Laning (1896), Ohio (1905) and Egan } \\
\text { (1910). }\end{array}$ \\
\hline Oklahoma & $\mathrm{No}$ & & $\begin{array}{l}\text { The practice of midwifery was unregulated (Egan 1910; van Blarcom } \\
\text { 1913; Pennell and Stewart 1968; Butter and Kay 1988). }\end{array}$ \\
\hline Oregon & $\mathrm{No}$ & & $\begin{array}{l}\text { The practice of midwifery was unregulated (Egan 1910; van Blarcom } \\
\text { 1913; Pennell and Stewart 1968; Butter and Kay 1988). }\end{array}$ \\
\hline Pennsylvania & Yes & 1913 & $\begin{array}{l}\text { Beginning in 1914, applicants were required to pass an examination } \\
\text { administered by the Bureau of Medical Education and Licensure and } \\
\text { penalties for practicing midwifery without a license came into effect } \\
\text { (van Blarcom 1913; Pennsylvania State Department of Health 1913, } \\
\text { pp. 8-9; Stevens 1914, p. 404; Miller and Baker 1916, p. 1000). }\end{array}$ \\
\hline Rhode Island & Yes & 1918 & $\begin{array}{l}\text { The law came into effect on July 1,1918. It required applicants to be } \\
\text { examined by the State Board of Health and stipulated penalties for } \\
\text { practicing midwifery without a license. Persons practicing midwifery } \\
\text { without a license were subject to a fine of up to } \$ 100 \text { and/or } \\
\text { imprisonment for up to } 6 \text { months. See Rhode Island (1918) for the full } \\
\text { text of the law. }\end{array}$ \\
\hline South Carolina & Yes & 1920 & $\begin{array}{l}\text { Midwives were required to receive basic instruction from public health } \\
\text { nurses in order to obtain a permit. Beginning in the early 1940s, } \\
\text { midwives were required to be able to read and write, "see well, have } \\
\text { average intelligence and be in good general health." New midwives } \\
\text { were required to attend a two-week course of instruction "at an annual } \\
\text { State or district midwife institute" before receiving a certificate "at the } \\
\text { discretion" of the county health officer. Certified midwives were } \\
\text { required to attend "a two weeks institute every four years." See Dodd } \\
\text { (1920), South Carolina (1960) and Hill (2012) for details. }\end{array}$ \\
\hline South Dakota & $\mathrm{No}$ & & $\begin{array}{l}\text { The practice of midwifery was unregulated (Egan 1910; van Blarcom } \\
\text { 1913; Pennell and Stewart 1968; Butter and Kay 1988). }\end{array}$ \\
\hline
\end{tabular}




\begin{tabular}{|c|c|c|c|}
\hline Tennessee & $\mathrm{No}$ & & $\begin{array}{l}\text { The practice of midwifery was unregulated (Egan 1910; van Blarcom } \\
\text { 1913; Pennell and Stewart 1968; Butter and Kay 1988). }\end{array}$ \\
\hline Texas & Yes & 1907 & $\begin{array}{l}\text { The Medical Practice Act required applicants to be } 21 \text { years of age, of } \\
\text { good moral character and to have graduated from a "bon fide, } \\
\text { reputable" medical school. Applicants were examined by the Board of } \\
\text { Medical Examiners in obstetrics, but the law did "not apply to those } \\
\text { who do not follow obstetrics as a profession, and who do not advertise } \\
\text { themselves as obstetricians or midwives." Persons practicing obstetrics } \\
\text { without a license were subject to a fine of up to } \$ 500 \text { and/or } \\
\text { imprisonment for up to } 6 \text { months. See Daniel (1910), Egan (1910) and } \\
\text { Texas (1916) for more details. }\end{array}$ \\
\hline Utah & Yes & 1907 & $\begin{array}{l}\text { The law required a license to practice obstetrics, but permitted the } \\
\text { practice of obstetrics "in case of emergency" and in communities } \\
\text { "where there are no licensed practitioners." Applicants were required } \\
\text { to pass an examination administered by the Board of Medical } \\
\text { Examiners. See Egan (1910) for more details. }\end{array}$ \\
\hline Vermont & No & & $\begin{array}{l}\text { A } 1906 \text { law stipulated that the practice of midwifery be unrestricted } \\
\text { (van Blarcom 1913). }\end{array}$ \\
\hline Virginia & Yes & 1919 & $\begin{array}{l}\text { The law required that midwives register with the local registrar and } \\
\text { "obey the sanitary rules of the State Board of Health." Persons } \\
\text { convicted of practicing the profession of midwifery without a permit } \\
\text { were subject to a fine in "a sum not less than ten dollars and not more } \\
\text { than fifty dollars." See Virginia (1918) and Pennell and Stewart (1968). }\end{array}$ \\
\hline Washington & Yes & 1917 & $\begin{array}{l}\text { The law required that applicants receive } 14 \text { months of training from a } \\
\text { "legally incorporated school on midwifery in good standing" and pass } \\
\text { an examination administered by the Board of Medical Examiners. Any } \\
\text { person practicing midwifery without a license "shall be deemed guilty } \\
\text { of a misdemeanor." For details see Washington (1919), Smith (2005, } \\
\text { pp. 55-56) and Varney and Thompson (2016, p. 143). }\end{array}$ \\
\hline West Virginia & Yes & 1925 & $\begin{array}{l}\text { The law into effect on January 11, 1926. Applicants for licensure had } \\
\text { to be at least } 21 \text { years of age, able to read and write, show habits of } \\
\text { cleanliness and have good moral character. A diploma from a school } \\
\text { of midwifery or a physician's statement verifying that the applicant had } \\
\text { attended at least five births was required. See Bickley (1990) for more } \\
\text { details. }\end{array}$ \\
\hline Wisconsin & Yes & 1909 & $\begin{array}{l}\text { The law came into effect in December, 1909. It required applicants to } \\
\text { have graduated from a reputable midwifery school, pass an } \\
\text { examination administered by the Medical Board of Examiners and } \\
\text { furnish evidence of "good moral and professional character." To be } \\
\text { considered reputable, a school had to offer at least } 12 \text { months of } \\
\text { instruction and practical experience in at least } 20 \text { "cases of } \\
\text { confinement." See Wisconsin (1909) for the full text of the law. }\end{array}$ \\
\hline Wyoming & Yes & 1899 & $\begin{array}{l}\text { Examination and licensure by the State Board of Medical Examiner } \\
\text { (van Blarcom 1913; Pennell and Stewart 1968). The law allowed the } \\
\text { practice of obstetrics or midwifery without a license "in cases of } \\
\text { emergency." See Wyoming (1899) for the full text of the law. }\end{array}$ \\
\hline
\end{tabular}




\section{Sources for Appendix Table 1}

Bickley, Ancella. 1990. “Midwifery in West Virginia.” West Virginia History, 49: 55-68.

Butter, Irene and Bonnie Kay. 1988. "State Laws and the Practice of Lay Midwifery." American Journal of Public Health, 78(9): 1161-1169.

Burns, Harrison. 1914. Burns' Annotated Indiana Statutes: Volume IV. Indianapolis, IN: The BobbsMerrill Company.

Cadwallader, Marian. 1957. "Midwife Training in Georgia: Needs and Problems." Bulletin of the American College of Nurse-Midwifery, 2(2): 18-23.

Colorado (state). 1915. Laws Passed at the Twentieth Session of the General Assembly of the State of Colorado, Chapter 148. An Act Relating to the Practice of Medicine in the State of Colorado. Denver, CO: Western Newspaper Union, State Printer.

Connecticut (State). 1893. Public Acts Passed by the General Assembly of the State of Connecticut in the Year 1893, Chapter CLVIII, An Act Concerning the Practice of Medicine, Surgery, and Midwifery. Hartford, CT: Press of the Fowler and Miller Company.

Daniel, M.E. 1910. "Results of the State Board Examination, November 9-11, 1909, at Greenville Texas." Texas State Journal of Medicine, 5(9): 357.

Declercq, Eugense. 1994. "The Trials of Hanna Porn: The Campaign to Abolish Midwifery in Massachusetts." American Journal of Public Health, 84(6): 1022-1028. Available at: http://www.ncbi.nlm.nih.gov/pmc/articles/PMC1614962/pdf/amjph00457-0144.pdf.

Dodd, Ruth. 1920. "Midwife Supervision in South Carolina." Public Health Nurse, 12(12): 863-867.

Duffy, John (editor). 1962. The Rudolph Matas History of Medicine in Louisiana, Volume II. Baton Rouge, LA: Louisiana State University Press.

Egan, James. 1910. "State Medical Licensing Boards." Medical Record: A Weekly Journal of Medicine and Surgery, 78(December 7): 1120-1127.

Georgia Department of Public Health. 1928. "Child Hygiene” by Joe P. Bowdoin. , pp. 27-28. Report of Georgia State Board of Health for 1927 and 1928. Atlanta, GA.

Georgia (state). 1957. "Rules of the Department of Public Health, Physical Health, Chapter 270-5-7, Midwifery."

Gray, Kathleen. 2015. “New Bills Give and Take Away Powers, and More.” Detroit Free Press, June 13. Available at: http://www.freep.com/story/news/politics/2015/06/13/roundup-newest-bills-introducedlansing $/ 71190240 /$. 
Hanson, Henry. 1931. "Protection of Motherhood." Florida Health Notes, 23(10): 149-150. Available at:

https://archive.org/stream/FloridaHealthNotes1931/1931 23\#page/n147/mode/2up/search/mid wifery.

Henning, Wilbur Fisk and William Harvey Hyatt. 1921. Henning's General Laws of California as Amended and in Force at the Close of the Forty-Third Session of the Legislature, 1919: Including Initiative and Referendum Acts Adopted at the General Election of 1920. The Practice of Medicine Act of 1913, Act 2809, Amendment of April 11, 1917. San Francisco, CA: Bender-Moss Company.

Hill, Patricia Evridge. 2012. "Dr. Hilla Sheriff. Caught between Science and the State at the South Carolina Midwife Training Institutes.” In Marjorie Julian Spruill, Valinda W. Littlefield and Joan Marie Johnson (eds.), South Carolina Women: Their Lives and Times, Volume 3. Athens, GA: University of Georgia Press.

Illinois State Board of Health. 1884. Official Register of Physicians and Midwives Now in Practice: To Whom Certificates Have Been Issued by the State Board of Health of Illinois: 1877-1884. Springfield IL: H.W. Rokker, State Printer and Binder.

Kennedy, John. 1921. "Safeguarding Maternity.” The New Republic, 26(327): 45.

Kentucky (state). 1922. The Kentucky Statutes, Containing All General Laws (not Included in the Codes of Practice) with Full Notes from Decisions of the Court of Appeals and the Constitution of Kentucky Annotated, $6^{\text {th }}$ edition. “Health; State Board of' Chapter 63, \$2054. Louisville Kentucky: The Baldwin Law Book Company.

Laning, J.F. (editor). 1896. Obio Legal News, Volume 3, "Practice of Medicine." pp. 166-168. Norwalk, $\mathrm{OH}$ : Laning Printing Company.

Levy, Julius. 1921. "Report of the Bureau of Child Hygiene" In the Fourth-Fourth Annual Report of the Department of Health of the State of New Jersey. Trenton, NJ: State of New Jersey.

Louisiana (state). 1904. Constitution and Revised Laws of Louisiana, Act 47, 1894, p. 55. Practice of Medicine, Surgery, and Midwifery. New Orleans, LA: F.F. Hansell and Bro., LTD.

Maryland (state). 1914. The Annotated Code of the Public Civil Laws of Maryland, Volume 3. Bagby, George (editor), Midwives, Chapter 722, Section 55A, P. 144. Baltimore, MD: King Bros., Printers and Publishers.

Miller, Herman P. and W. Harry Baker. 1916. Smull's Legislative Handbook and Manual of the State of Pennsylvania, 1916. Harrisburg, PA: WM. Stanley Bay, State Printer.

Minnesota (state). 1891. General Laws of the State of Minnesota for Passed during the Twenty-Seventh Session of the State Legislature, Chapter 30, An Act to Regulate the Practice of Midwifery in the State of Minnesota. St. Paul, MN: The Pioneer Press Company.

Mississippi Board of Health. 1921. "Supervision of Midwives", pp. 197-199. In the Report of the Board of Health of Mississippi, Volume 2. Jacksonville, MS. 
Missouri (state). 1909. The Revised Statutes of the State of Missouri, 1909, Volume 2, Article II, Midwifery, Sections 8320-8323, pp. 2609-2610. Jefferson City, MO: Hugh Stephens Printing Company.

National Committee for the Prevention of Blindness. 1920. The News Letter, 28(October) pp. 4-5.

New Jersey State Board of Medical Examiners. 1902. Eleventh Annual Report of the State Board of Medical Examiners of New Jersey, Volume 11, Part 1901, Appendix D. Trenton, NJ: MacCrellish and Quigley, State Printers.

New York Department of Health. 1915. "Notes from the State Department of Health: The Control of Midwives." New York State Journal of Medicine, 15(8): 323.

North Carolina. 1920. Consolidated Statutes of North Carolina, Volume Two, Article 9, Chapter 110. Raleigh, NC: Edwards and Broughton, State Printers.

North Carolina. 1935. Public Laws and Resolutions Passed by the General Assembly at its Session of 1935. SB 188. Chapter 225. "An Act to Protect the Health of Mothers and Infants and to Regulate the Practice of Midwifery." Charlotte, NC: The Observer Printing House, Inc.

Ohio (state). 1905. "The Board of Medical Registration and Examination." In The Biographical Annals of Obio: A Handbook of the Government and Institutions of the State of Obio, pp. 625-630. Springfield, OH: The Springfield Publishing Company, State Printers.

Pennell, Maryland Young and Paula A. Stewart. 1968. State Licensing of Health Occupations. Washington DC: National Center for Health Statistics.

Pennsylvania State Department of Health. 1913. "Pennsylvania Health Legislation of 1913." Pennsylvania Bulletin of Health, No. 49 (August).

Perry, Diana. 1983. “The Early Midwives of Missouri.” Journal of Nurse-Midwifery, 28(6): 15-22.

Rhode Island (state). 1918. Public Laws of the State of Rhode Island and Providence Plantations Passed at the Sessions of General Assembly 1917 and 1918, Chapter 1634. Pawtucket, RI: Pawtucket Linotype Company.

Sandvick, Clinton. 2009. "Enforcing Medical Licensing in Illinois: 1877-1890.” Yale Journal of Biology and Medicine, 82(2): 67-74.

Smith, Susan L. 2005. Japanese American Midwives: Culture, Community, and Health Politics, 1880-1950. Chicago, IL: University of Illinois Press.

South Carolina. 1960. "Rules and Regulations Governing Midwives in the State of South Carolina", pp. 194-195. Code of Laws of South Carolina 1952, Annotated: 1960 Cumulative Supplement, Volume 7. Columbia, SC: R. L. Bryan Company.

Stevens, Cyrus Lee (editor). 1914. The Pennsylvania Medical Journal, 17(5). Athens, PA: W.G. Jordan Press. 
Stone, Wilbur Fiske (editor). 1918. History of Colorado, Volume 1. "The Medical Profession.” Chicago, IL: The S.J. Clarke Publishing Company.

Texas (state). 1916. Vernon's Criminal Statutes of Texas, Volume 1: The Penal Code, Chapter 6, Unlawful Practice of Medicine, Art 754. Kansas City, MO: Vernon Law Book Company.

Tovino, Stacey A. 2004. "American Midwifery Litigation and State Legislative Preferences for Physician-Controlled Childbirth.” Scholarly Works, Paper 394. Available at:

http:/ / scholars.law.unlv.edu/cgi/viewcontent.cgi?article=1395\&context=facpub.

van Blarcom, Carolyn Conant. 1913. The Midwife in England: Being a Study in England of the Working of The English Midwives Act of 1902. New York, NY: Committee for the Prevention of Blindness.

Varney, Helen and Joyce Thompson. 2016. A History of Midwifery in the United States: The Midwife said Fear Not. New York, NY: Springer Publishing Company.

Virginia (state). 1918. Acts of the General Assembly of the Commonwealth of Virginia, Chapter 58.

Richmond, VA: Davis Bottom, Superintendent of Public Printing.

Warsh, Cheryl Lynn Krasnick. 2010. Prescribed Norms: Women and Health in Canada and the United States Since 1800. Toronto, ON: University of Toronto Press.

Washington (state). 1919. Pierce's Code, State of Washington, Cyclopedic Arrangement, Including Laws 1919, Act 1917 to Regulate \$3755. Seattle, WA: National Law Book Company.

Williams, Linsly. 1915. "The Position of the New York State Department of Health Relative to the Control of Midwives.” New York State Journal of Medicine, 15(8): 296-301.

Wisconsin (state). 1909. The Laws of Wisconsin: Joint Resolutions and Memorials Passed at the Biennial Session of the Legislature, 1909, Chapter 528. Madison, WI: Democratic Printing Company, State Printer.

Wyoming (state). 1899. Session Laws of the State of Wyoming Passed by the Fifth State Legislature, Chapter 18, Section 15. Laramie, WY: Chaplin, Spafford and Mathison, Printers. 


\section{Appendix Table 2. States and Years Covered in State-Level Analysis, 1900-1940}

\begin{tabular}{cccc} 
State & Years Covered & State & Years Covered \\
\hline Alabama & $1925-1940$ & Nebraska & $1920-1940$ \\
Arizona & $1926-1940$ & Nevada & $1929-1940$ \\
Arkansas & $1927-1940$ & New Hampshire & $1900-1940$ \\
California & $1906-1940$ & New Jersey & $1900-1940$ \\
Colorado & $1906-1940$ & New Mexico & $1929-1940$ \\
Connecticut & $1900-1940$ & New York & $1900-1940$ \\
Delaware & $1919-1940$ & North Carolina & $1916-1940$ \\
Florida & $1919-1940$ & North Dakota & $1924-1940$ \\
Georgia & $1922-1924,1928-1940$ & Ohio & $1909-1940$ \\
Idaho & $1922-1940$ & Oklahoma & $1928-1940$ \\
Illinois & $1918-1940$ & Oregon & $1918-1940$ \\
Indiana & $1900-1940$ & Pennsylvania & $1906-1940$ \\
Iowa & $1923-1940$ & Rhode Island & $1900-1940$ \\
Kansas & $1914-1940$ & South Carolina & $1916-1940$ \\
Kentucky & $1911-1940$ & South Dakota & $1906-1909,1930-1940$ \\
Louisiana & $1918-1940$ & Tennessee & $1917-1940$ \\
Maine & $1900-1940$ & Texas & $1933-1940$ \\
Maryland & $1906-1940$ & Utah & $1910-1940$ \\
Massachusetts & $1900-1940$ & Vermont & $1900-1940$ \\
Michigan & $1900-1940$ & Virginia & $1913-1940$ \\
Minnesota & $1910-1940$ & Washington & $1908-1940$ \\
Mississippi & $1919-1940$ & West Virginia & $1925-1940$ \\
Missouri & $1911-1940$ & Wisconsin & $1908-1940$ \\
Montana & $1910-1940$ & Wyoming & $1922-1940$ \\
\hline
\end{tabular}

Notes: States that contributed date before and after a midwifery law was passed are denoted in italics. 


\section{Appendix Table 3. Examination in Midwifery Administered by the Wisconsin Medical Board of Examiners, 1926}

1. Describe the female organs of generation.

2. Give the symptoms of pregnancy during the first three months.

3. When you examine a woman in labor, how do you determine if the position is normal?

4. What would you do for the severe case of hemorrhage during labor until a physician could be called?

5. What are the symptoms of kidney trouble in the pregnant woman?

6. Describe the preparation of the woman in the beginning of labor. Also how do you prepare yourself?

7. How do you take care of the cord and the baby's eyes? Describe after care of the mother with especial reference to the nipples and genitals.

8. How do you deliver the placenta? In case a severe hemorrhage follows delivery of the placenta, what would you do?

9. If the baby does not breathe well or cry lustily, what do you do?

10. How do you feed a baby for the first three or four days? What do you use?

11. What would lead you to suspect a parturient woman would be likely to develop convulsions?

12. What benefit may be derived from your making a report of a birth? Why is it necessary so to report?

Notes: The original copy of this exam is available at http://ebling.library.wisc.edu/historical/wi-

women/exam questions.pdf. 


\section{Appendix Table 4. Municipality Midwifery Ordinances, 1900-1917}

\begin{tabular}{|c|c|c|}
\hline City and State & $\begin{array}{l}\text { ar Ordinat } \\
\text { Adopted }\end{array}$ & Description \\
\hline Alexandria, Virginia & 1912 & $\begin{array}{l}\text { Adopted on July } 23,1912 \text {. Applicants were examined by } \\
\text { the health officer of the city. Persons found guilty of } \\
\text { practicing midwifery without a license were subject to a } \\
\text { fine of "not less than } \$ 5 \text { nor more than } \$ 100 . "\end{array}$ \\
\hline Jacksonville, Florida & 1913 & $\begin{array}{l}\text { Effective April 1, 1914. Applicants had to pass an } \\
\text { examination administered by the city board of health. } \\
\text { The city board of health, in turn, was required to provide } \\
\text { instruction free of charge. "No test of the literacy or the } \\
\text { education of the applicants shall form part of the } \\
\text { examination." Any person "to assist for a compensation } \\
\text { of any kind a woman in normal childbirth" was subject to } \\
\text { the ordinance. Violation of the ordinance was } \\
\text { punishable by a fine of not more than } \$ 25 \text { or } \\
\text { imprisonment for up to } 30 \text { days. }\end{array}$ \\
\hline Los Angeles, California & 1910 & $\begin{array}{l}\text { Applicants were required to pass an examination } \\
\text { administered by board of health. The board of health was } \\
\text { also tasked with investigating the applicant and refusing } \\
\text { permits to those with a criminal history and to those } \\
\text { found to have committed immoral acts. Practicing } \\
\text { midwifery without a permit was punishable by a fine of } \\
\text { up to } \$ 500 \text { and/or imprisonment for up to } 6 \text { months. }\end{array}$ \\
\hline Marquette, Michigan & 1915 & $\begin{array}{l}\text { Applicants had to be } 21 \text { years of age, able to read and } \\
\text { write and pass an examination administered by the city } \\
\text { health officer. Based on the results of the examination, } \\
\text { her qualifications and her "experience as a midwife", the } \\
\text { city health officer was authorized to certify the applicant. } \\
\text { Violation of the ordinance was punishable by a fine of up } \\
\text { to } \$ 50 \text { or imprisonment for up to } 90 \text { days. }\end{array}$ \\
\hline Memphis, Tennessee & 1910 & $\begin{array}{l}\text { Effective August 9,1910. Applicants were required to } \\
\text { pass an examination administered by the superintendent } \\
\text { of health. In addition, applications for a permit had to be } \\
\text { signed by at least three "reputable citizens and taxpayers } \\
\text { of the city of Memphis, who certify to the good character } \\
\text { of the applicant." Practicing midwifery without a permit } \\
\text { was punishable by a fine of not less than } \$ 5 \text { but not more } \\
\text { than } \$ 50 \text {. Anyone acting as a midwife for "hire or } \\
\text { compensation" was subject to the ordinance. }\end{array}$ \\
\hline New York, New York & 1907 & $\begin{array}{l}\text { As of November } 6,1907 \text {, midwives were required to } \\
\text { obtain a permit issued by the New York City Board of } \\
\text { Health (Bell 1914). According to rules adopted by the } \\
\text { Board of Health, applicants were required to have } \\
\text { attended at least } 20 \text { deliveries under the supervision of a }\end{array}$ \\
\hline
\end{tabular}


physician. In addition, applicants had to be 21 years of age, of "moral character", able to read and write and "show evidences... of habits of cleanliness." The homes and equipment of midwives had to be available for inspection "at all times." New rules took effect on April 1, 1914. Under the new rules, applicants were required to have graduated from a registered school of midwifery. See New York Department of Health (1909), Bell (1914), New York Bureau of Child Hygiene (1915) and New York Department of Health (1915) for more details.

Norfolk, Virginia $1912 \quad$ Adopted July 16, 1912. Applicants were required to
receive a permit from the city health commissioner who was empowered to "refuse such permit in any case where in his judgement it is not advisable to grant the same." Violations of the ordinance were punishable by a fine of up to $\$ 20$.

Raleigh, North Carolina

1912 Adopted on July 19, 1912. Midwives were required to register in the office of the board of health and provide the name and location of the "college or school or other institution from which such person received a diploma, certificate or license." Neglecting to register was punishable with a fine of $\$ 10$ per day.

Syracuse, New York

1913 Effective April 7, 1913. Midwives were examined and licensed by the Board of Examiners in Midwifery, appointed by the mayor. Applicants had to be 21 years of age. The board was empowered to exam applicants "as to their moral character and qualifications to practice midwifery." Violation of the law was punishable by a fine not less than $\$ 50$ but not more than $\$ 100$. According to the New York Department of Health (1915), the city of Syracuse "has not exercised any systematic supervision of the midwives licensed."

\section{Sources for Appendix Table 4}

Alexandria, VA. 1913. "Births and Deaths-- Registration of." Ordinance Adopted July 23, 1912. Source: Public Health Reports (1896-1970), 28(8): 372-375. Available at: http://www.jstor.org/stable/pdf/4569281.pdf?acceptTC=true.

Bell, Rosalie. 1914. "The Supervision of Midwives in the City of New York." Monthly Bulletin of the Department of Health in the City of New York, 4(6): 166-172.

Jacksonville, FL. 1913. "Midwifery--Regulation of the Practice of.” Ordinance M-41, December 31, 1913. Source: Municipal Ordinances, Rules, and Regulations Pertaining to Public Health Adopted 1910-1914 by Cities of the U.S. Having a Population of Over 10,000 in 1910 (1915). Washington, DC: Government Printing Office. 
Los Angeles, CA. 1910. "Midwifery and Lying-In Houses.” Ordinance adopted on July 19, 1910. Source: Municipal Ordinances, Rules, and Regulations Pertaining to Public Hygiene Adopted from January 1 1910, to June 30, 1911 by Cities in the United States Having a Population over 25,000 in 1910 (1913). Washington, DC: Government Printing Office.

Marquette, MI. 1915. "Midwifery-Practice of-License Required.” Ordinance adopted on October 18, 1915. Municipal Ordinances, Rules, and Regulations Pertaining to Public Health 1915 (1917). Washington, DC: Government Printing Office.

Memphis, TN. 1910. "Midwifery_Practice of." Ordinance adopted on August 9, 1910. Source: Municipal Ordinances, Rules, and Regulations Pertaining to Public Hygiene Adopted from January 1 1910, to June 30, 1911 by Cities in the United States Having a Population over 25,000 in 1910 (1913). Washington, DC: Government Printing Office.

New York Department of Health. 1909. "Regulations Governing the Practice of Midwifery in the City of New York." Annual Report of the Dept. of Health of the City of New York. New York, NY: Martin B. Brown and Company, Printers and Stationers.

New York Bureau of Child Hygiene.1915. "Midwifery_Practice of-Schools for." In the Municipal Ordinances, Rules, and Regulations Pertaining to Public Health 1915 (1917). Washington, DC: Government Printing Office.

New York Department of Health. 1915. "Notes from the State Department of Health: The Control of Midwives." New York State Journal of Medicine, 15(8): 323.

Norfolk, VA. 1912. "Physicians, Surgeons, and Midwives-Registration of." Ordinance, July 19, 1912. Source: Municipal Ordinances, Rules, and Regulations Pertaining to Public Health Adopted from July 1, 1911 to December 31, 1911 by Cities of the United States Having a Population of over 10,000 in 1910 (1913). Washington, DC: Government Printing Office.

Raleigh, NC. 1912. "Board of Health-Organization, Powers, and Duties." Chapter XX, Ordinance July 19, 1912. Source: Municipal Ordinances, Rules, and Regulations Pertaining to Public Health Adopted from July 1, 1911 to December 31, 1911 by Cities of the United States Having a Population of over 10,000 in 1910 (1913). Washington, DC: Government Printing Office.

Syracuse Midwifery Act, Chapter 227. Source: Charter of the City of Syracuse Consisting of Second Class Cities Law and Special Statutes Together with General Ordinances, and Rules and Regulations of the Boards, Bureaus, Offices and Departments of the City of Syracuse (1915). 


\section{Appendix Table 5. States and Years Covered in Municipal-Level Analysis, 1900-1917}

\begin{tabular}{cccccc} 
State & $\begin{array}{c}\text { Number of } \\
\text { Cities in Sample }\end{array}$ & Years Covered & State & $\begin{array}{c}\text { Number of } \\
\text { Cities in Sample }\end{array}$ & Years Covered \\
\hline Alabama & 3 & $1900-1917$ & Nebraska & 2 & $1900-1917$ \\
Arizona & 0 & $\ldots$ & Nevada & 0 & $\ldots$ \\
Arkansas & 0 & $\ldots$ & New Hampshire & 7 & $1900-1917$ \\
California & 11 & $1900-1917$ & New Jersey & 27 & $1900-1917$ \\
Colorado & 4 & $1900-1917$ & New Mexico & 0 & $\ldots$ \\
Connecticut & 20 & $1900-1917$ & New York & 45 & $1900-1917$ \\
Delaware & 1 & $1900-1917$ & North Carolina & 2 & $1900-1917$ \\
Florida & 2 & $1900-1917$ & North Dakota & 0 & $\ldots$ \\
Georgia & 2 & $1900-1917$ & Ohio & 21 & $1900-1917$ \\
Idaho & 0 & $\ldots$ & Oklahoma & 0 & $\ldots$ \\
Illinois & 9 & $1900-1917$ & Oregon & 1 & $1900-1917$ \\
Indiana & 21 & $1900-1917$ & Pennsylvania & 51 & $1900-1917$ \\
Iowa & 4 & $1900-1905$ & Rhode Island & 9 & $1900-1917$ \\
Kansas & 3 & $1900-1917$ & South Carolina & 1 & $1900-1917$ \\
Kentucky & 4 & $1900-1917$ & South Dakota & 0 & $\ldots$ \\
Louisiana & 1 & $1900-1917$ & Tennessee & 2 & $1900-1915,1917$ \\
Maine & 8 & $1900-1917$ & Texas & 2 & $1900-1917$ \\
Maryland & 4 & $1900-1917$ & Utab & 2 & $1900-1917$ \\
Massachusetts & 52 & $1900-1917$ & Vermont & 3 & $1900-1917$ \\
Michigan & 23 & $1900-1917$ & Virginia & 6 & $1900-1917$ \\
Minnesota & 5 & $1900-1917$ & Washington & 4 & $1900-1917$ \\
Mississippi & 0 & $\ldots$ & West Virginia & 1 & $1900-1917$ \\
Missouri & 3 & $1900-1917$ & Wisconsin & 18 & $1900-1917$ \\
Montana & 0 & $\ldots$ & Wyoming & 0 & $\ldots$ \\
\hline
\end{tabular}

Notes: States with cities that contributed data before and after a midwifery law was passed are denoted in italics. 


\section{Appendix Table 6. Descriptive Statistics for Municipal-Level Maternal Mortality Analysis, 1900-1917}

\begin{tabular}{|c|c|c|c|c|}
\hline & Full sample & $\begin{array}{l}\text { Midwifery License } \\
\text { Required }=1\end{array}$ & $\begin{array}{l}\text { Midwifery License } \\
\text { Required }=0\end{array}$ & Description \\
\hline \multirow[t]{2}{*}{ Maternal Mortality } & $16.0(11.0)$ & $16.2(11.1)$ & $15.8(11.0)$ & Maternal mortality per 100,000 population \\
\hline & $\mathrm{N}=6,365$ & $\mathrm{~N}=2,635$ & $\mathrm{~N}=3,730$ & \\
\hline Physician Diploma & $.825(.380)$ & $.980(.139)$ & $.715(.451)$ & $=1$ if state required physicians to have a diploma \\
\hline Physician Education & $.741(.438)$ & $.912(.283)$ & $.620(.485)$ & $\begin{array}{l}=1 \text { if state medical boards could set preliminary education } \\
\text { requirements }\end{array}$ \\
\hline Dept. of Public Health & $.998(.045)$ & $1.00(0.00)$ & $.997(.059)$ & $=1$ if state had a public health department \\
\hline Dept. of Child Hygiene & $.079(.269)$ & $.128(.334)$ & $.043(.204)$ & $=1$ if state had a division of child hygiene \\
\hline Suffrage & $.049(.217)$ & $.052(.221)$ & $.048(.214)$ & $=1$ if women were allowed to vote \\
\hline Typhoid & $27.9(28.5)$ & $25.5(24.9)$ & $29.5(30.8)$ & Typhoid mortality per 100,000 population \\
\hline Non-pulmonary TB & $22.5(13.4)$ & $22.5(13.3)$ & $22.5(13.5)$ & Non-pulmonary tuberculosis mortality per 100,000 population \\
\hline
\end{tabular}

Notes: Unweighted means with standard deviations in parentheses. 